\title{
Dynamics of organic and inorganic carbon across contiguous mangrove and seagrass systems (Gazi Bay, Kenya)
}

\author{
Steven Bouillon, ${ }^{1,2}$ Frank Dehairs, ${ }^{1}$ Branko Velimirov, ${ }^{3}$ Gwenaël Abril, ${ }^{4}$ \\ and Alberto Vieira Borges ${ }^{5}$ \\ Received 22 September 2006; revised 16 January 2007; accepted 19 February 2007; published 9 May 2007.
}

[1] We report on the water column biogeochemistry in adjacent mangrove and seagrass systems in Gazi Bay (Kenya), with a focus on assessing the sources and cycling of organic and inorganic carbon. Mangrove and seagrass-derived material was found to be the dominant organic carbon sources in the water column, and could be distinguished on the basis of their $\delta^{13} \mathrm{C}$ signatures and particulate organic carbon:total suspended matter (POC/TSM) ratios. Spatially, a distinct boundary existed whereby the dominance of mangrove-derived material decreased sharply close to the interface between the mangrove forest and the dense seagrass beds. The latter is consistent with the reported export of mangrove-derived material, which is efficiently trapped in the adjacent seagrass beds. There were significant net inputs of POC and dissolved organic carbon (DOC) along the Kidogoweni salinity gradient, for which the $\delta^{13} \mathrm{C}_{\mathrm{POC}}$ signatures were consistent with those of mangroves. DOC was the dominant form of organic carbon in both mangrove and seagrass beds, with DOC/POC ratios typically between 3 and 15. Dynamics of dissolved inorganic carbon in the creeks were strongly influenced by diagenetic $\mathrm{C}$ degradation in the intertidal mangrove areas, resulting in significant $\mathrm{CO}_{2}$ emission from the water column to the atmosphere. Although highest partial pressure of $\mathrm{CO}_{2}\left(\mathrm{pCO}_{2}\right)$ values and areal $\mathrm{CO}_{2}$ flux rates were observed in the mangrove creeks, and the water column above the seagrass beds was in some locations a net sink of $\mathrm{CO}_{2}$, most of the ecosystems' emission of $\mathrm{CO}_{2}$ to the atmosphere occurred in the seagrass beds adjacent to the mangrove forest. The presence of dense seagrass beds thus had a strong effect on the aquatic biogeochemistry, and resulted in trapping and further mineralization of mangrove-derived POC, intense $\mathrm{O}_{2}$ production and $\mathrm{CO}_{2}$ uptake. The adjacent seagrass beds provide a large area with conditions favorable to exchange of $\mathrm{CO}_{2}$ with the atmosphere, thereby limiting export of mangrove-derived organic and inorganic carbon toward the coastal ocean.

Citation: Bouillon, S., F. Dehairs, B. Velimirov, G. Abril, and A. V. Borges (2007), Dynamics of organic and inorganic carbon across contiguous mangrove and seagrass systems (Gazi Bay, Kenya), J. Geophys. Res., 112, G02018, doi:10.1029/2006JG000325.

\section{Introduction}

[2] Given the importance of the tropics in the global riverine export of organic and inorganic carbon $(\sim 60 \%$ according to the empirical model by Ludwig et al. [1996]), the lack of data on the magnitude of carbon sources and fluxes from river systems along the east African coastline represents one of the many gaps in our knowledge

\footnotetext{
${ }^{1}$ Department of Analytical and Environmental Chemistry, Vrije Universiteit Brussel, Brussels, Belgium.

${ }^{2}$ Also at Centre for Estuarine and Marine Ecology, Netherlands Institute of Ecology (NIOO-KNAW), Yerseke, Netherlands

${ }^{3}$ Center for Anatomy and Cell Biology, Medical University of Vienna, Vienna, Austria.

${ }^{4}$ Environnements et Paléoenvironnements Océaniques (EPOC), CNRSUMR 5805, Université Bordeaux 1, Talence, France.

${ }^{5}$ Unité d'Océanographie Chimique, MARE, Université de Liège, Sart Tilman, Belgium.
}

Copyright 2007 by the American Geophysical Union. 0148-0227/07/2006JG000325\$09.00 on carbon dynamics in the tropical coastal zone [Bouillon et al., 2007]. Moreover, significant changes in the quantity and composition of organic matter may take place during estuarine transit and in nearshore coastal environments. The majority of estuaries and deltas along the east African coastline are bordered by intertidal mangrove forests, highly productive coastal ecosystems which may induce major changes in the metabolic state of estuaries [e.g., Bouillon et al., 2003, 2007; Borges et al., 2003]. The sediments and water column may receive high inputs of organic matter, either directly as leaf and wood litter or as dissolved organic carbon, typically resulting in a heterotrophic metabolic status and hence, a significant flux of $\mathrm{CO}_{2}$ to the atmosphere, the latter, however, not being sufficiently constrained for upward scaling to a worldwide level [Borges et al., 2003, 2005].

[3] The fate of mangrove production has long been an issue of debate in the literature. Earlier reports considered these systems as supplying large amounts of carbon sufficient to sustain heterotrophic secondary production in 


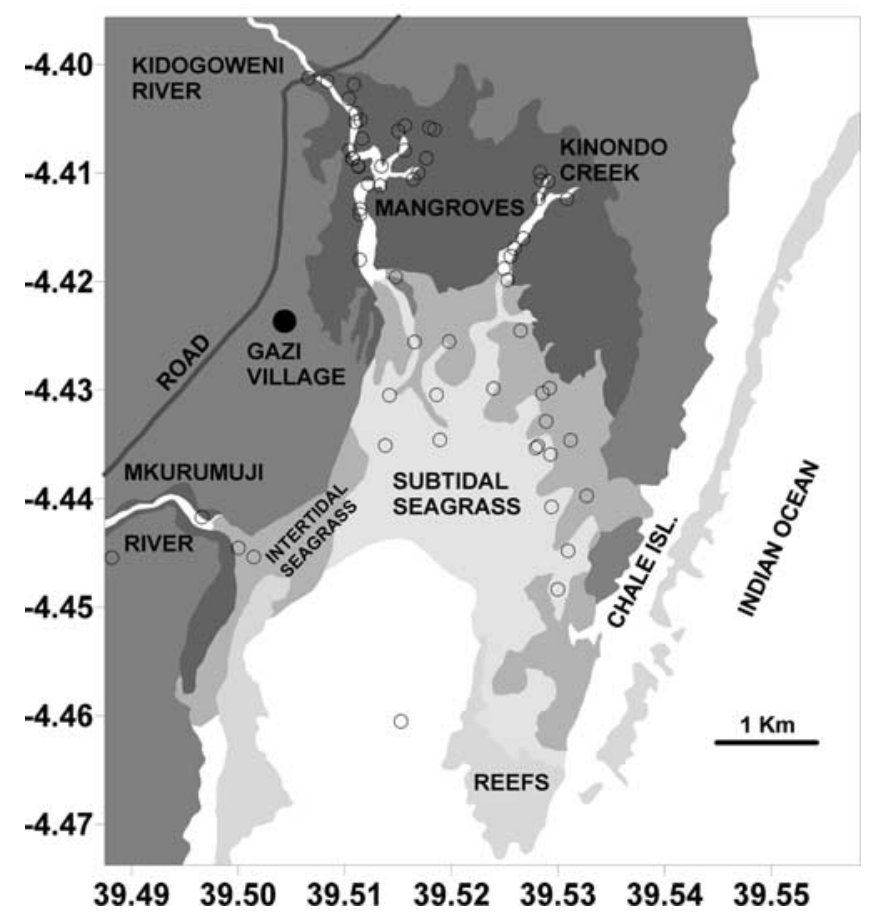

Figure 1. Map of Gazi Bay, indicating mangrove and seagrass-covered areas and the location of the sampling stations.

nearshore areas, but later studies have demonstrated that this is not always the case [Lee, 1995]. The geographical extent to which mangrove-derived carbon can be traced is in many cases quite limited to a fringing zone of less than a few $\mathrm{km}$ [e.g., Xu et al., 2006]. Nevertheless, exported mangrove material has been hypothesized to comprise up to $10 \%$ of the total riverine organic carbon inputs to the ocean [Jennerjahn and Ittekkot, 2002; Dittmar et al., 2006]. In many studies, however, the term "exported" only implies that mangrove carbon reaches the estuarine or creek water column, but has no implication as to its ultimate fate; few studies have attempted to trace mangrove carbon further offshore [Dittmar et al., 2006]. The estimates by Jennerjahn and Ittekkot [2002], for example, assume that little or no mineralization takes place once mangrove carbon leaves the intertidal zone. The potential significance of mineralization has recently gained some attention, as mangrove-surrounding waters typically show a large oversaturation in $\mathrm{CO}_{2}$ with respect to atmospheric equilibrium [e.g., Borges et al., 2003; Bouillon et al., 2003; 2007]. Although more quantitative data are needed, this suggests that mineralization in subtidal sediments and the water column in tidal creeks and adjacent areas could represent a major fate of mangrove carbon exported from the intertidal zone.

[4] Seagrass beds influence water flow patterns resulting in increased sedimentation, trapping of autochtonous and allochtonous suspended matter, and reducing the degree of sediment resuspension. On the other hand, a literature compilation by Duarte and Cebrián [1996] suggests that a significant fraction of seagrass production ( $25 \%)$ may also be exported out of the system. Previous studies in the study area (Gazi Bay, Kenya) have indicated that mangrove carbon is indeed exported from the intertidal areas but that the adjacent seagrass beds appear to be highly efficient in trapping this material, where it contributes significantly to benthic mineralization [Hemminga et al., 1994; Bouillon et al., 2004a].

[5] Our study site (Gazi Bay, Kenya) represents a typical sequence of contiguous mangrove, seagrass and coral reef ecosystems, and offers a good case to study the flow and processing of carbon between such adjacent systems. We sampled the mangrove creeks and seagrass beds during the dry season of 2003 for a suite of physico-chemical and biogeochemical parameters, focusing on the distribution and sources of organic and inorganic carbon. In addition, we wanted to assess the importance and spatial patterns of $\mathrm{CO}_{2}$ exchange between the water column and atmosphere.

\section{Materials and Methods}

\subsection{Site Description}

[6] Gazi Bay $\left(39^{\circ} 30^{\prime} \mathrm{E}, 4^{\circ} 22^{\prime} \mathrm{S}\right.$, Figure 1) is located $\sim 50 \mathrm{~km}$ south of Mombasa, and covers a total area of $\sim 10 \mathrm{~km}^{2}$, with an additional 6 to $7 \mathrm{~km}^{2}$ covered by mangroves, mostly Rhizophora mucronata, Sonneratia alba, Ceriops tagal, Bruguiera gymnorrhiza, Avicennia marina, and Xylocarpus granatum. Seagrasses (mainly Thalassodendron ciliatum) form dense beds in the lower parts of Kinondo creek and cover $\sim 70 \%$ of the bay area [Coppejans et al., 1992]. The bay opens into the Indian Ocean through a relatively wide but shallow entrance in the southern part. The upper region of the bay receives freshwater through the Kidogoweni river which crosses the mangroves. A second river, the Mkurumuji, opens into the southwestern part of the Bay and is reported to have a higher annual discharge than the Kidogeweni [Kitheka et 
al., 1996]. During the time of sampling, however, the Mkurumuji behaved as a partially closed and stratified estuary, with freshwater occurring in the upper water layer up to the river mouth; hence, mixing with water from the Bay occurred in a very narrow zone. Spring tidal range in Gazi Bay is around $3 \mathrm{~m}$ [Kitheka, 1997]. Both mangroves and seagrass beds in this area are known to be highly productive. Production by Thalassodendron ciliatum (the dominant seagrass species in the bay) has been reported as ranging between 710 and $1365 \mathrm{~g} \mathrm{C} \mathrm{m}^{-2} \mathrm{yr}^{-1}$ [Hemminga et al., 1995], and litterfall data for Ceriops tagal, Rhizophora mucronata, and Avicennia marina correspond to litter production of 164,412 , and $236 \mathrm{~g} \mathrm{C} \mathrm{m}^{-2} \mathrm{yr}^{-1}$, respectively [Slim et al., 1996a; Ochieng and Erftenmeijer, 2002]. The latter should be considered as underestimates of total mangrove production since it does not include belowground production and wood production. Although more thorough productivity assessments are lacking, annual production by these two communities is likely to be of similar magnitude considering the areal extent of mangroves and seagrasses in the study site (e.g., see Figure 1).

\subsection{Sampling and Analytical Techniques}

[7] Samples were collected during a 3-week period in July and August 2003 at various locations, including the Kidogoweni and Mkurumuji rivers, Kinondo creek, several smaller side creeks of the Kidogoweni (Makongeni and Sikuti creek) and various stations in the bay area (Figure 1). At one station located centrally in the bay area, samples were collected on an hourly basis during a 24-hour period (southernmost station on Figure 1), but the diurnal variations are not discussed in detail here. Wind speed was measured with a handheld anemometer. Surface water for field measurements of dissolved $\mathrm{O}_{2}, \mathrm{pH}$, temperature and salinity were taken with a 1.7 L Niskin bottle $\sim 0.5 \mathrm{~m}$ below the surface. Oxygen saturation level $\left(\mathrm{OO}_{2}\right)$ was measured immediately after collection with a polarographic electrode (WTW Oxi-340) calibrated on saturated air, with an accuracy of $\pm 1 \%$. The $\mathrm{pH}$ was measured using a Ross type combination electrode (ORION) calibrated on the NBS (US National Bureau of Standards) scale, as described by Frankignoulle and Borges [2001], with a reproducibility of $\pm 0.005 \mathrm{pH}$ units. Samples for determination of total alkalinity (TA) were obtained by prefiltering $100 \mathrm{~mL}$ of water through precombusted Whatman GF/F filters, filtration through $0.2 \mu \mathrm{m}$ Acrodisc syringe filters, and were stored in HDPE bottles until analysis by automated electro-titration on $50 \mathrm{~mL}$ samples with $0.1 \mathrm{M} \mathrm{HCl}$ as titrant (reproducibility better than $\pm 4 \mu \mathrm{mol} \mathrm{kg}{ }^{-1}$ ). The partial pressure of $\mathrm{CO}_{2}$ $\left(\mathrm{pCO}_{2}\right)$ and dissolved inorganic carbon concentrations (DIC) were computed from $\mathrm{pH}$ and TA measurements with the thermodynamic constants described by Frankignoulle and Borges [2001], with the accuracy of computed DIC and $\mathrm{pCO}_{2}$ values estimated at $\pm 5 \mu \mathrm{mol} \mathrm{kg}{ }^{-1}$ and better than $\pm 2 \%$, respectively.

[8] Water samples for the analysis of $\delta^{13} \mathrm{C}_{\mathrm{DIC}}$ and $\delta^{18} \mathrm{O}_{\mathrm{DO}}$ were taken from the same Niskin bottle by gently overfilling 10 or $20 \mathrm{~mL}$ glass headspace vials, respectively, poisoning with $20 \mu \mathrm{L}$ of a saturated $\mathrm{HgCl}_{2}$ solution, and gas-tight capping with a butylrubber plug and aluminium cap. For the analysis of $\delta^{13} \mathrm{C}_{\mathrm{DIC}}$, a He headspace was created, and $\sim 300 \mu \mathrm{L}$ of $\mathrm{H}_{3} \mathrm{PO}_{4}$ was added to convert all inorganic carbon species to $\mathrm{CO}_{2}$. After overnight equilibration, part of the headspace was injected into the He stream of an EA-IRMS (ThermoFinnigan Flash1112 and ThermoFinnigan Delta $+\mathrm{XL}$ ) for $\delta^{13} \mathrm{C}$ measurements. The obtained $\delta^{13} \mathrm{C}$ data were corrected for the isotopic equilibration between gaseous and dissolved $\mathrm{CO}_{2}$ using the algorithm presented in Miyajima et al. [1995]. For $\delta^{18} \mathrm{O}_{\mathrm{DO}}$, a similar headspace was created in the $20 \mathrm{~mL}$ vials, after which they were left to equilibrate for 2 hours. The $\delta^{18} \mathrm{O}_{\mathrm{DO}}$ was then measured using the same EA-IRMS setup by monitoring $\mathrm{m} / \mathrm{z} 32,33$, and 34 and using a $5 \ddot{\mathrm{A}}$ molecular sieve column to separate $\mathrm{N}_{2}$ from $\mathrm{O}_{2}$. Outside air was used as a standard to correct all $\delta^{18} \mathrm{O}$ data.

[9] Samples for $\mathrm{Ca}^{2+}$ and $\mathrm{Mg}^{2+}$ were taken as described below for dissolved organic carbon (DOC), and preserved with $10 \mu \mathrm{L}$ of ultrapure $\mathrm{HNO}_{3} . \mathrm{Ca}^{2+}$ and $\mathrm{Mg}^{2+}$ concentrations were measured by inductively coupled plasma-atomic emission spectrometry (ICP-AES) and showed a reproducibility better than $3 \%$. Samples for $\mathrm{PO}_{4}^{3-}$ were similarly obtained and preserved with $\mathrm{HgCl}_{2}\left(1 \mu \mathrm{L} \mathrm{mL} \mathrm{m}^{-1}\right.$ sample $)$. Samples for $\mathrm{Si}$ were prepared by filtration on $0.45 \mu \mathrm{m}$ Sartorius cellulose nitrate filters, and preserved with $100 \mu \mathrm{L}$ of $\mathrm{HCl}(30 \%)$ for $20 \mathrm{~mL}$ of sample. $\mathrm{PO}_{4}^{3-}$ and $\mathrm{Si}$ were analyzed by standard colorimetric methods [Grasshoff et al., 1983], with a precision of $\pm 0.1 \mu \mathrm{M}$.

[10] Samples for total suspended matter (TSM) were stored in a cool box before filtration on preweighed and precombusted (overnight at $450^{\circ} \mathrm{C}$ ) $47 \mathrm{~mm}$ Whatman $\mathrm{GF} / \mathrm{F}$ filters, and subsequently dried. For nonfreshwater stations, filters were briefly rinsed with mineral water to avoid a contribution by salts. Samples for particulate organic carbon (POC), particulate nitrogen (PN), and $\delta^{13} \mathrm{C}_{\mathrm{POC}}$ were filtered on precombusted $25 \mathrm{~mm}$ Whatman $\mathrm{GF} / \mathrm{F}$ filters and dried. These filters were later decarbonated with $\mathrm{HCl}$ fumes under partial vacuum for 4 hours, redried and packed in Ag cups. POC and PN were determined on a ThermoFinnigan Flash EA1112 using acetanilide as a standard, and the resulting $\mathrm{CO}_{2}$ was measured on a ThermoFinnigan delta $+\mathrm{XL}$ interfaced via a ConfloIII to the EA. Reproducibility of $\delta^{13} \mathrm{C}_{\mathrm{POC}}$ measurements was better than $\pm 0.2 \%$. Samples for DOC were obtained by prefiltering surface water on precombusted glass fiber filters (Whatman GF/F, $0.7 \mu \mathrm{m}$ ), further filtration on $0.2 \mu \mathrm{m}$ Acrodisc syringe filters, and were preserved by the addition of $50 \mu \mathrm{l}$ of $\mathrm{H}_{3} \mathrm{PO}_{4}$ per $15 \mathrm{~mL}$ of sample. DOC was measured with a high-temperature catalytic oxidation analyzer (Shimadzu TOC 5000); replicates showed an accuracy around $\pm 50 \mu \mathrm{g} \mathrm{L}^{-1}$. Samples for Chlorophyll a (hereafter $\mathrm{Chl} \mathrm{a)}$ were obtained by filtering a known volume of surface water on glass fiber filters $(0.7 \mu \mathrm{m}$, Whatman GF/F). These were kept frozen in the field laboratory, transported to the home laboratory on dry ice, and then stored at $-20^{\circ} \mathrm{C}$. Pigments were extracted for approximately 12 hours in $15 \mathrm{~mL}$ of $90 \%$ acetone at $4^{\circ} \mathrm{C}$ and analyzed with a Turner TD-700 Fluorometer. The accuracy of $\mathrm{Chl}$ a analysis was estimated to be $\pm 4 \%$.

[11] Samples for the estimation of bacterial abundance were preserved with formaldehyde $(2 \% \mathrm{v} / \mathrm{v})$. Cells were counted and sized by epifluorescence microscopy and the acridine orange direct counting technique [Hobbie et al., 1977], whereby at least 20 fields per subsample were counted. Volume estimations were based on the assumption that all cells are spheres or rods, i.e., cylinders with two hemispherical caps [Velimirov and Valenta-Simon, 1992]. 
Table 1. Summary of Elemental (\%TOC, TOC/TN) Composition of Sediments, and $\delta^{13} \mathrm{C}$ Values of Sediment Organic Carbon, Plant Biomass (Seagrasses, Mangroves), and Bacterial PLFA in the Mangroves and Seagrass Beds of Gazi Bay, Kenya ${ }^{\text {a }}$

\begin{tabular}{|c|c|c|c|c|}
\hline & \multicolumn{2}{|c|}{ Seagrass Beds } & \multicolumn{2}{|c|}{ Mangroves } \\
\hline & Average \pm 1 s.d. & Range & Average \pm 1 s.d. & Range \\
\hline$\% \mathrm{TOC}$ & $1.7 \pm 1.9 \%$ & 0.3 to $7.0 \%$ & $5.6 \pm 4.5 \%$ & 0.6 to $14.6 \%$ \\
\hline $\mathrm{TOC} / \mathrm{TN}$ & $12.4 \pm 3.4$ & 8.3 to 19.9 & $16.7 \pm 2.2$ & 12.4 to 22.8 \\
\hline$\delta^{13} \mathrm{C}_{\mathrm{TOC}}$ & $-21.2 \pm 3.3 \%$ & -25.5 to $-16.0 \%$ & $-25.1 \pm 0.8 \%$ & -26.5 to $-22.1 \%$ \\
\hline$\delta^{13} \mathrm{C}_{\text {plant }}$ & $-14.3 \pm 2.9 \%$ & -18.6 to $-10.7 \%$ & $-28.7 \pm 1.7 \%$ & -31.2 to $-26.8 \%$ \\
\hline$\delta^{13} \mathrm{C}_{\mathrm{i}+\mathrm{a} 15: 0}$ & $-25.9 \pm 3.7 \%$ & -31.5 to $-21.1 \%$ & $-29.7 \pm 2.5 \%$ & -35.6 to $-26.1 \%$ \\
\hline
\end{tabular}

${ }^{\mathrm{a}}$ Data are from Bouillon et al. [2004a, 2004b].

At least 50 cells per morphotype and subsample (i.e., 600 cells per sample) were sized in length and width, and this procedure was calibrated with fluorescent latex beads with diameters of $0.1,0.2,0.6$ and $0.88 \mu \mathrm{m}$. Cellular carbon content in $\mathrm{fg} \mathrm{C}$ cell $^{-1}$ was calculated from estimated cell volumes $\left(\mathrm{V}, \mu \mathrm{m}^{3}\right)$ assuming the allometric relation $\mathrm{C}=120 \mathrm{~V}^{0.72}$ [Norland, 1993].

[12] Data on $\delta^{13} \mathrm{C}$ of potential carbon sources from the same sampling period (e.g., mangroves, seagrasses) have been presented elsewhere in a different context [Bouillon et al., 2004a, 2004b] and are summarized in Table 1.

\section{Results}

[13] TSM ranged between 2.0 and $70.5 \mathrm{mg} \mathrm{L}^{-1}$, with highest values $\left(27.4-70.5 \mathrm{mg} \mathrm{L}^{-1}\right)$ in the Mkurumuji river (Figure 2a). In the Kidogoweni river, TSM in the oligohaline zone was generally low $\left(2-7 \mathrm{mg} \mathrm{L}^{-1}\right)$ except for a single station with high TSM $\left(22.9 \mathrm{mg} \mathrm{L}^{-1}\right)$. TSM gradually increased along the salinity gradient (Figure 2a), reaching values around $20 \mathrm{mg} \mathrm{L}^{-1}$ in the marine part of the estuary. TSM in the seagrass-covered bay varied between 5.2 and $25.2 \mathrm{mg} \mathrm{L}^{-1}$ and showed a significant correlation with wind speed $\left(r^{2}=0.29, p<0.001\right.$, figure not shown), suggesting that part of the TSM in this shallow bay was resuspended sediment material.

[14] POC concentrations ranged from 144 to $1913 \mu \mathrm{gC} \mathrm{L}^{-1}$. The trend in POC along the salinity gradient of the Kidogoweni is somewhat scattered, but clearly indicates high net inputs of POC in the estuary (Figure $2 b$ ). POC in both the freshwater part and the marine end-member is lower than $500 \mu \mathrm{gC} \mathrm{L}^{-1}$, whereas POC at intermediate salinity varies between $\sim 400$ and $1900 \mu \mathrm{gC} \mathrm{L}^{-1}$. POC values from other mangrove creeks followed the trend observed in the Kidogoweni, but Kinondo creek had markedly higher POC (up to $1550 \mu \mathrm{g} \mathrm{L}^{-1}$ ) than other locations with similar salinity. POC in the seagrass beds was typically lower, and the majority of data from the bay area range between 200 and $400 \mu \mathrm{gC} \mathrm{L}{ }^{-1}$.

[15] POC made up between 0.9 and $16.7 \%$ of the total suspended matter. Low POC/TSM ratios were found in the Mkurumuji estuary when compared to the Kidogoweni
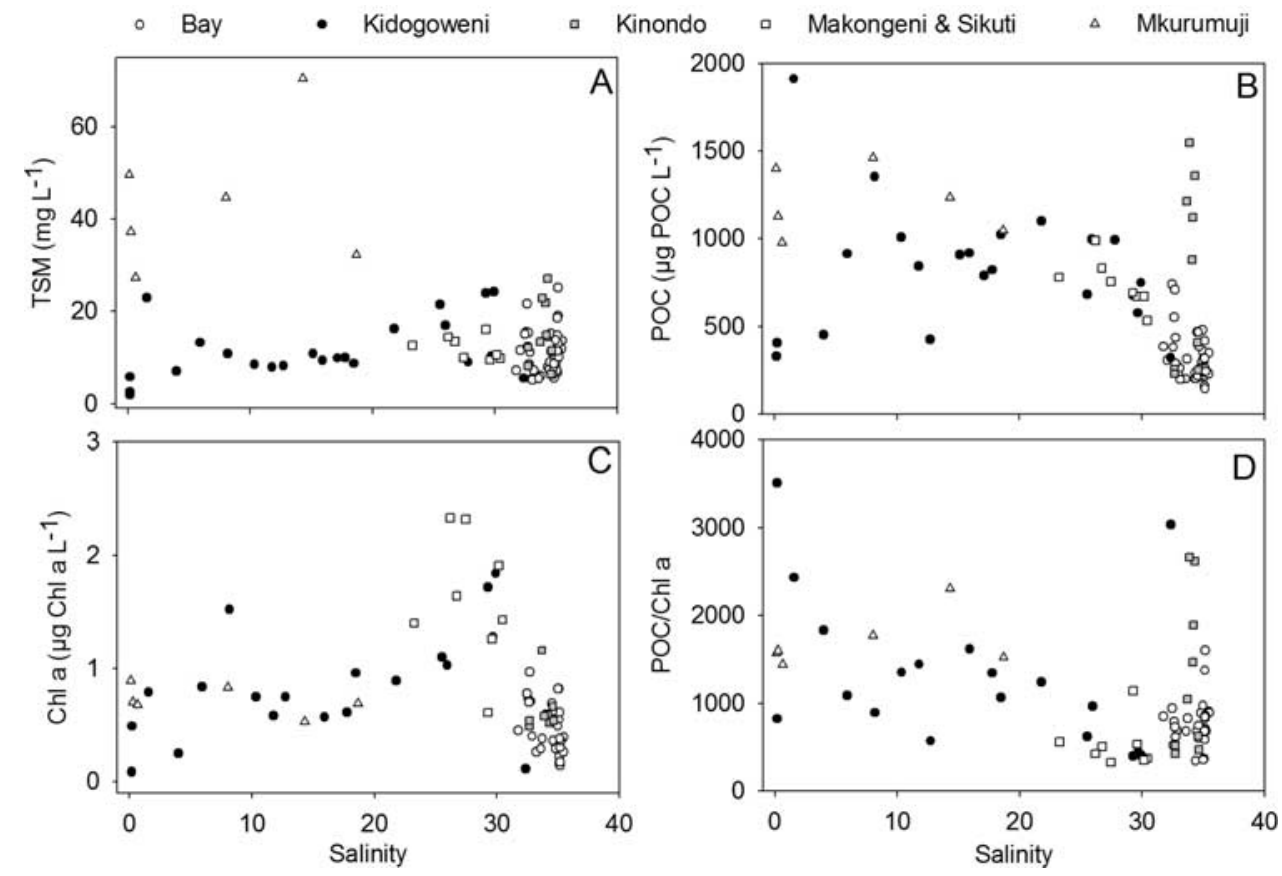

Figure 2. Distribution of (a) TSM, (b) POC, (c) Chl a, and (d) POC/Chla ratios as a function of salinity for the different sampling areas considered. 

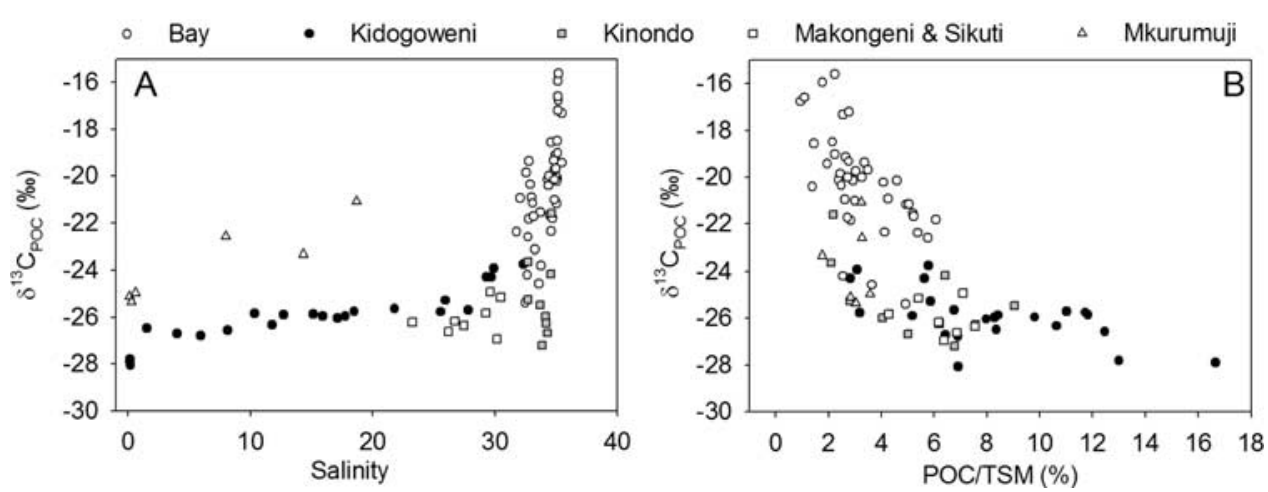

Figure 3. Distribution of (a) $\delta^{13} \mathrm{C}_{\mathrm{POC}}$ along the salinity gradient and (b) relationship between POC/ TSM and $\delta^{13} \mathrm{C}_{\mathrm{POC}}$.

estuary. In the latter, POC/TSM ratios vary widely between 2.8 and $16.7 \%$ (average $8.3 \pm 3.5 \%, \mathrm{n}=22$ ), and although there is a wide scatter in the data, POC/TSM tends to decrease with increasing salinity (not shown). In the seagrass-covered bay area, POC/TSM values are typically lower and less scattered, averaging $3.2 \pm 1.3 \%(\mathrm{n}=42)$. $\mathrm{Chl}$ a concentrations were consistently low in the entire study area (mostly between 0.2 and $1.0 \mu \mathrm{g}$ Chla $\mathrm{L}^{-1}$ ), with a general increase at the interface between the mangrove creeks and seagrass beds in the salinity range of 25-30 (Figure 2c). Consequently, $\mathrm{POC} / \mathrm{Chl}$ a values were very high (Figure 2d), generally $>800 \mu \mathrm{g} \mathrm{C} \mu \mathrm{g} \mathrm{Chla}^{-1}$ with lowest values in the salinity range of $25-30$.

[16] The $\delta^{13} \mathrm{C}_{\mathrm{POC}}$ varied between -28.1 and $-14.5 \%$, and showed a very marked pattern along the salinity gradient (Figure 3a). For the Kidogoweni, $\delta^{13} \mathrm{C}_{\mathrm{POC}}$ in the freshwater/oligohaline zone is around -28 to $-27 \%$, and increased only slightly (to $\sim-26 \%$ ) up to a salinity of $\sim 30$. The $\delta^{13} \mathrm{C}_{\mathrm{POC}}$ in other mangrove creeks (Kinondo, Makongeni, Swere and Sikuti) is generally lower than in the Kidogoweni at similar salinity (Figure $3 \mathrm{a}$ ). In the seagrasscovered bay, $\delta^{13} \mathrm{C}_{\mathrm{POC}}$ increases drastically up to a maximum of $-14.5 \%$. In the Mkurumuji, however, $\delta^{13} \mathrm{C}_{\mathrm{POC}}$ is much more enriched than in the Kidogoweni. The more negative $\delta^{13} \mathrm{C}_{\mathrm{POC}}$ are associated with higher \%POC/TSM (Figure $3 \mathrm{~b}$ ) and with higher $\mathrm{POC} / \mathrm{Chl}$ a ratios (similar trend, figure not shown).

[17] DOC concentrations ranged from $\sim 5000-$ $6000 \mu \mathrm{gC} \mathrm{L}^{-1}$ in the freshwater and oligohaline zone of the Kidogoweni and Mkurmuji rivers, and decreased steadily toward the bay area, where minimal values between 1200 and $1500 \mu \mathrm{gC} \mathrm{L}{ }^{-1}$ were reached (Figure 4a). DOC comprised the dominant form of organic carbon in the water column, representing $64-95 \%$ of the total aquatic organic carbon pool (Figure 4b). The DOC distribution pattern (Figure 4a) showed a clear nonconservative behavior, with significant internal production or inputs of DOC along most of the salinity gradient, both in the Kidogoweni estuary, Kidogoweni creek, and many of the seagrass stations.

[18] The bacterial counts on samples from a selected number of stations indicated that bacterial $\mathrm{C}$ constituted between 0.3 and $5.1 \%$ of the POC pool (data not shown). Bacterial abundance (Figure 5) showed an increasing trend along the salinity gradient of the Kidogoweni to reach maximal values in the salinity range of $25-30$ where the maximum Chla concentrations where observed. In the bay, bacterial abundance showed a linear decrease with salinity $\left(\mathrm{r}^{2}\right.$ of 0.78 for salinities ranging from 32.7 to 35.2). Overall, bacterial abundance was higher in the Kidogoweni $\left(361 \pm 18510^{3}\right.$ cells $\left.\mathrm{mL}^{-1}, \mathrm{n}=11\right)$ than in the bay $\left(292 \pm 16010^{3}\right.$ cells $\left.\mathrm{mL}^{-1}, \mathrm{n}=21\right)$.

[19] Oxygen levels were consistently undersaturated with respect to atmospheric equilibrium along the salinity gradient
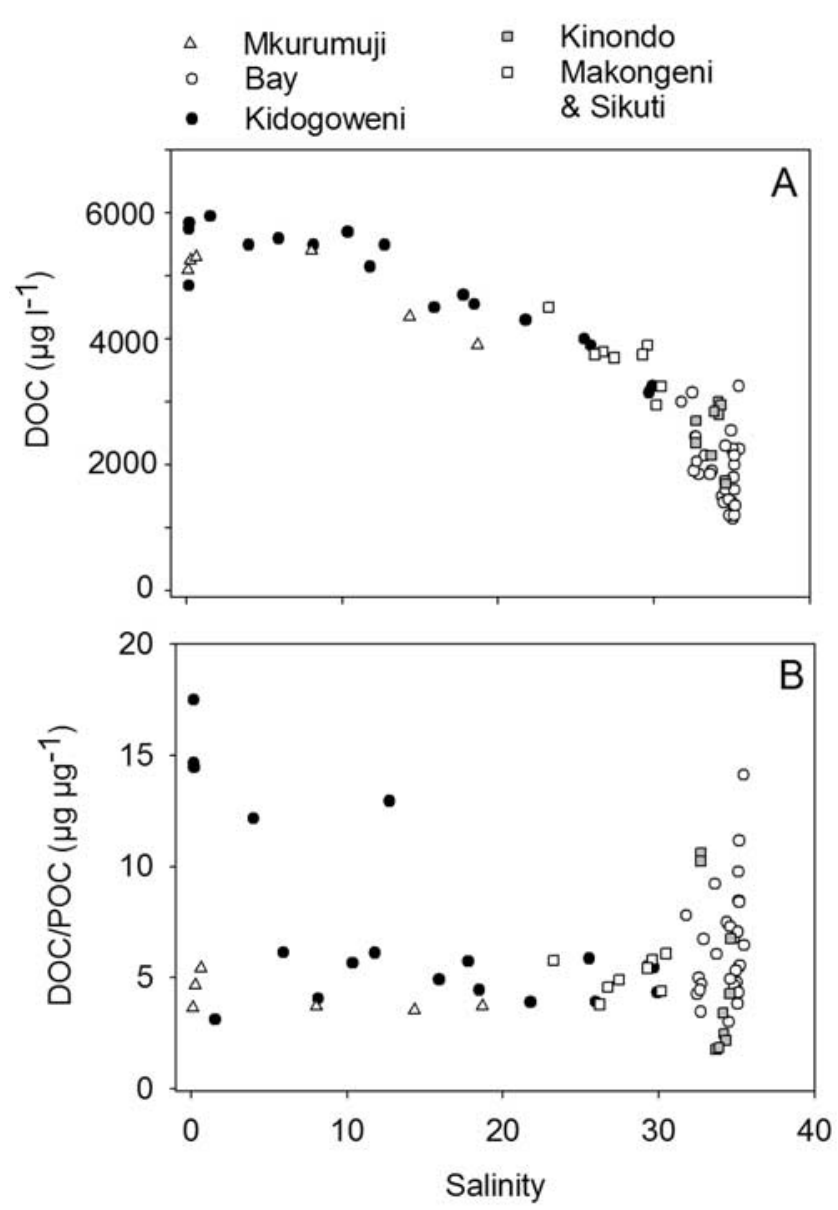

Figure 4. Distribution of (a) DOC and (b) DOC/POC ratios as function of salinity. 


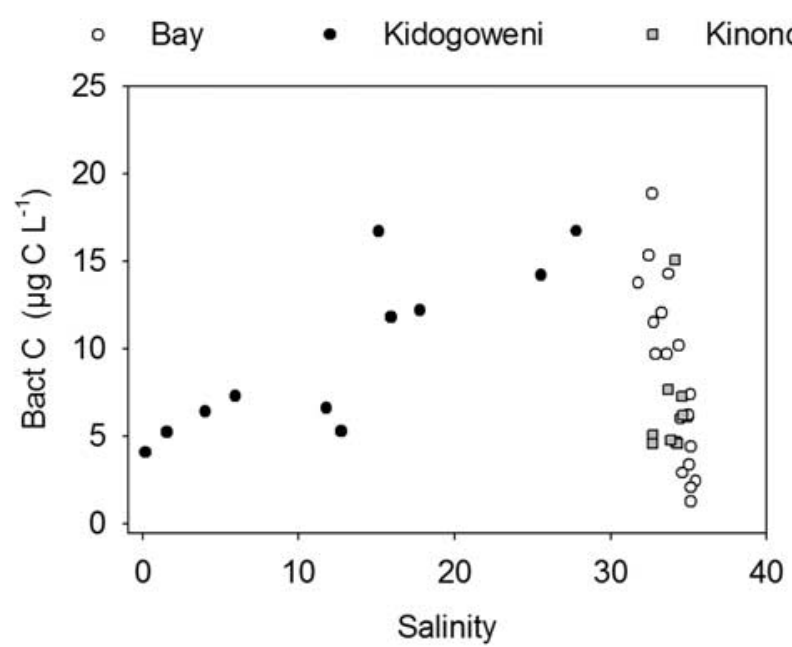

Figure 5. Distribution of bacterial abundance (in terms of bacterial C) as a function of salinity.

of the Kidogoweni estuary and other mangrove creeks. A marked increase in $\% \mathrm{O}_{2}$ was observed above the seagrass beds, with maximum values reaching $\sim 200 \%$ (Figure 6a). The $\delta^{18} \mathrm{O}$ composition of dissolved $\mathrm{O}_{2}$ ranged between
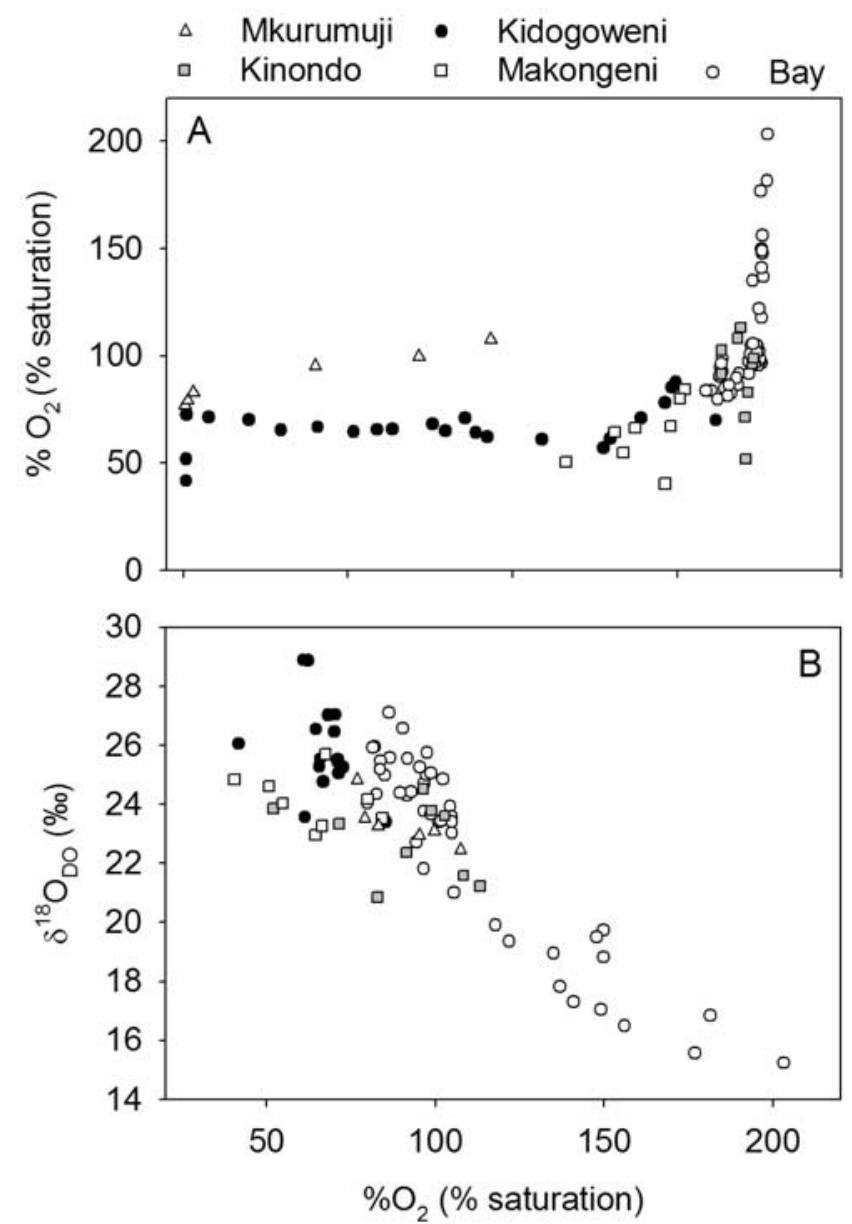

Figure 6. (a) Distribution of $\% \mathrm{O}_{2}$ along the salinity gradient and (b) relationship between $\delta^{18} \mathrm{O}_{\mathrm{DO}}$ and $\% \mathrm{O}_{2}$ for the different sampling areas.
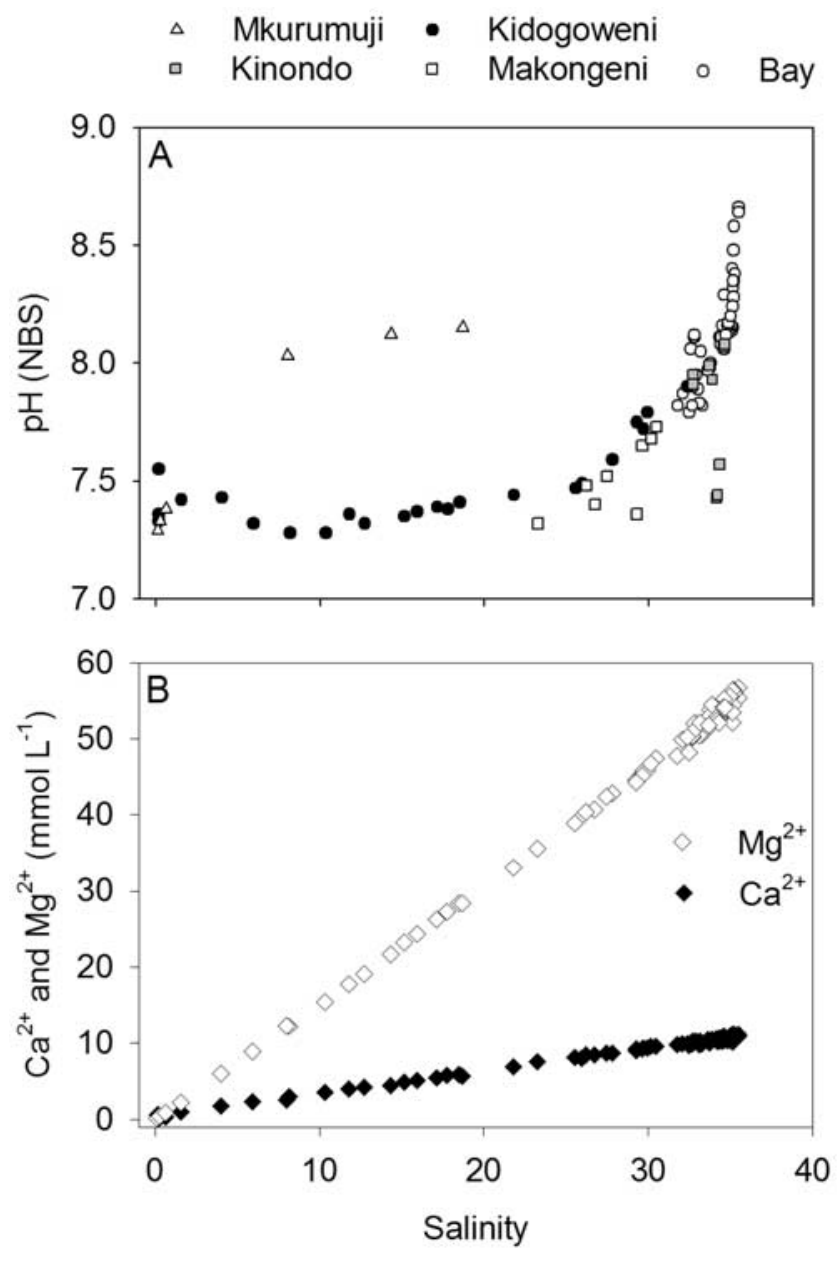

Figure 7. Distribution of (a) $\mathrm{pH}$ and (b) $\mathrm{Ca}^{2+}$ and $\mathrm{Mg}^{2+}$ along the salinity gradient.

$+28.9 \%$ and $+15.2 \%$, and showed a general inverse relationship with $\% \mathrm{O}_{2}$ (Figure 6b). $\mathrm{pH}$ levels in the Kidogoweni estuary ranged between 7.28 and 7.79 and showed a minimum in the mesohaline zone (Figure 7a). In the seagrass beds, $\mathrm{pH}$ was consistently higher and ranged between 7.79 and 8.66 (Figure 7a). Both $\mathrm{Ca}^{2+}$ and $\mathrm{Mg}^{2+}$ showed conservative behavior whatever the considered ecosystem (Figure 7b). TA and DIC showed conservative behavior in the Mkurumuji estuary, but clear internal production along the Kidogoweni salinity gradient (Figures 8a and $8 \mathrm{~b}$ ). Higher TA and DIC values were observed in Makongeni creek, whereas TA and DIC levels in the seagrass beds showed a decreasing trend with salinity (Figures $8 \mathrm{a}$ and $8 \mathrm{~b}$ ). Consistent with these trends, $\delta^{13} \mathrm{C}_{\mathrm{DIC}}$ profiles were close to that expected for conservative mixing in the Mkurumuji estuary (Figure 8c), but the latter was not the case for the Kidogoweni and other mangrove creeks where $\delta^{13} \mathrm{C}_{\mathrm{DIC}}$ was more negative than expected under a conservative mixing scenario. Highest $\delta^{13} \mathrm{C}_{\text {DIC }}$ values of up to $+1.7 \%$ were found above the seagrass beds. $\mathrm{pCO}_{2}$ values were above atmospheric equilibrium in the Kidogwoneni and mangrove creeks, ranging between 575 and $6435 \mathrm{ppm}$ (Figure 8d), with a maximum along the Kidogoweni. In the seagrass beds, however, $\mathrm{pCO}_{2}$ values were markedly lower 

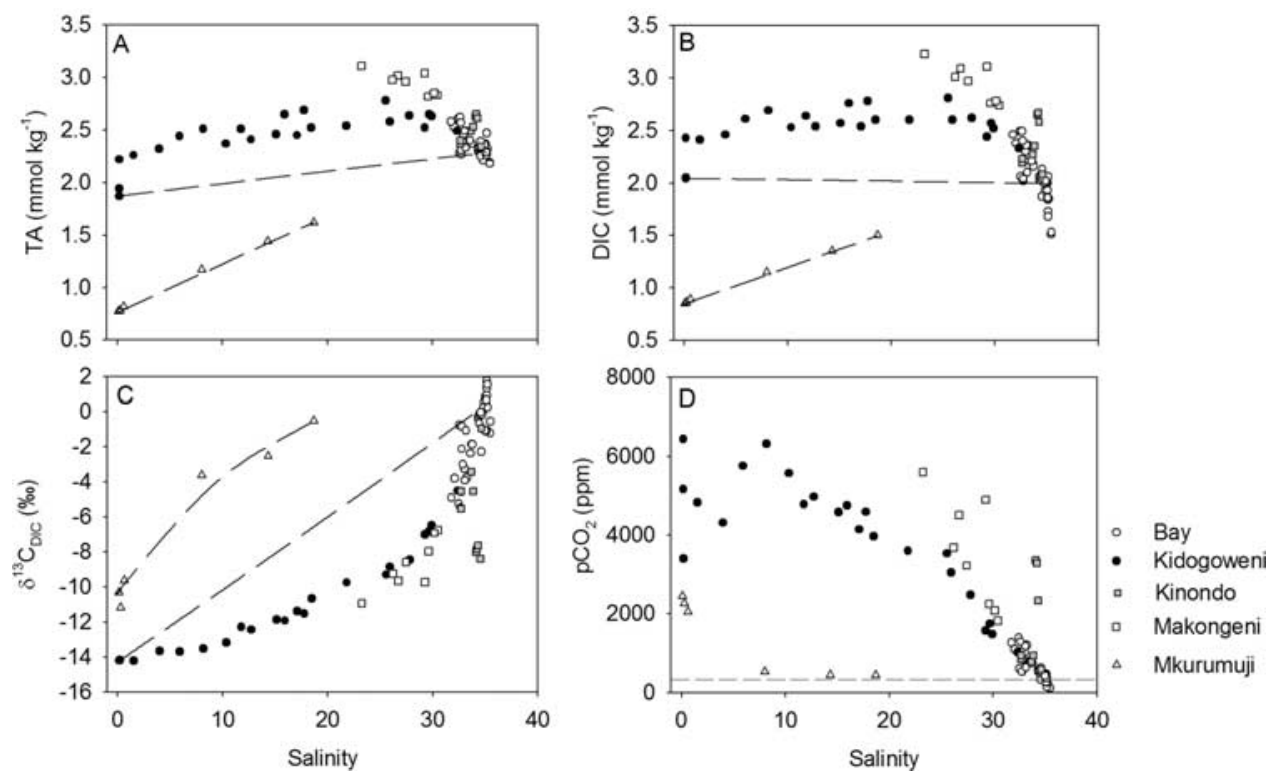

Figure 8. Inorganic carbon distribution and stable isotope composition along the salinity gradient. (a) TA, (b) DIC, (c) $\delta^{13} \mathrm{C}_{\mathrm{DIC}}$, and (d) $\mathrm{pCO}_{2}$. The dotted lines in Figure s $8 \mathrm{a}-8 \mathrm{c}$ indicate the distribution expected for conservative mixing (see text for details); dotted line on Figure $8 \mathrm{~b}$ represents the average atmospheric $\mathrm{pCO}_{2}(362 \mathrm{ppm})$.

(maximum of $1388 \mathrm{ppm}$ ), and a number of stations showed distinct undersaturation with respect to atmospheric equilibrium, with a minimal $\mathrm{pCO}_{2}$ value of $106 \mathrm{ppm}$. The $\mathrm{pCO}_{2}$ in the Mkurumuji was relatively high in the freshwater and oligohaline zone (2050-2450 ppm) but decreased rapidly with higher salinity to values between 430 and $530 \mathrm{ppm}$.

[20] Silicate concentrations in the freshwater part of the Kidogoweni reached $\sim 150 \mu \mathrm{mol} \mathrm{kg}{ }^{-1}$, showed a nonconservative increase in the 5-10 salinity range and decreased linearly with increasing salinity (Figure 9a). The distribution of $\mathrm{Si}$ in the Mkurumuji estuary was similar, albeit with slightly lower Si levels in the freshwater end. Phosphate levels were fairly stable along the salinity gradient of the Kidogoweni, ranging between $\sim 0.5 \mu \mathrm{mol} \mathrm{L}^{-1}$ in the freshwater part to $\sim 0.2 \mu \mathrm{mol} \mathrm{L}^{-1}$ near the mouth (Figure $9 \mathrm{~b}$ ). In the seagrass beds and Kinondo creek, $\mathrm{PO}_{4}^{3-}$ concentrations at many sampling locations showed a clear increase (Figure 9b).

\section{Discussion}

\subsection{Sources of Organic Carbon in the Water Column}

[21] On the basis of the $\delta^{13} \mathrm{C}$ signatures of primary producers and POC, we can distinguish two major sources of organic carbon in the water column: mangrove-derived $\mathrm{C}$ with a $\delta^{13} \mathrm{C}$ signature of $\sim-28 \%$, and seagrass-derived $\mathrm{C}$, the latter with a spatially variable but distinctly more enriched $\delta^{13} \mathrm{C}$ signature between -19 and $-11 \%$ (Table 1). Considering the overall low $\mathrm{Chl}$ a concentrations (Figure 2c) and high $\mathrm{POC} / \mathrm{Chl}$ a ratios (Figure $2 \mathrm{~d}$ ), the contribution of phytoplankton biomass to the POC pool can be assumed to be minimal: typical $\mathrm{POC} / \mathrm{Chl}$ a ratios for living phytoplankton are in the range of 30-100 [e.g., Abril et al., 2002, and references therein] whereas observed $\mathrm{POC} / \mathrm{Chl}$ a ratios are typically $>800$ (Figure $2 \mathrm{~d}$ ). The two major endmembers (mangroves and seagrasses) are not only characterized by different $\delta^{13} \mathrm{C}$ signatures, but also by different $\mathrm{POC} / \mathrm{TSM}$ ratios as evident from the relationship between $\delta^{13} \mathrm{C}$ and POC/TSM (Figure 3b): at locations where mangrove-derived $\mathrm{C}$ dominates, POC makes up $8 \%$ or more of the TSM pool, whereas this contribution gradually decreases to values between 2 and $4 \%$ for stations where seagrass-derived $\mathrm{C}$ is the dominant source of POC. In contrast, POC/PN ratios do not show a consistent trend along the salinity gradient, and there is no discernable relationship between $\delta^{13} \mathrm{C}_{\mathrm{POC}}$ and $\mathrm{POC} / \mathrm{PN}$ (data not shown). Previously, Kitheka et al. [1996] suggested that seagrass material contributes only minimally to the POC pool in this area and that the more enriched $\delta^{13} \mathrm{C}$ signatures of POC in the bay are due to marine (i.e., phytoplankton) inputs. Our Chl a data, however, show that marine phytoplankton is insignificant and that the $\delta^{13} \mathrm{C}_{\mathrm{POC}}$ signal is rather due to an important contribution by seagrass material. At the boundary of the mangrove-seagrass interface, however, coinciding with a salinity of $\sim 30$, the $\delta^{13} \mathrm{C}$ signature of POC changes drastically, from about $-26 \%$ at the mouth of Kidogoweni to values as high as $-14 \%$, indicative of a fairly abrupt change in the relative contribution of mangrove and seagrass-derived organic carbon (Figure 3a). This marked spatial gradient indicates that in both habitats, the majority of the suspended POC load is of local origin, even though bidirectional exchange of organic carbon between both systems is known to occur [Hemminga et al., 1994]. The contrast in the origin of POC is consistent with the fact that exported mangrove-derived material is efficiently trapped in the seagrass beds adjacent to the forest, where it contributes to the sedimentary organic carbon pool and has been shown to provide a substantial input for benthic 


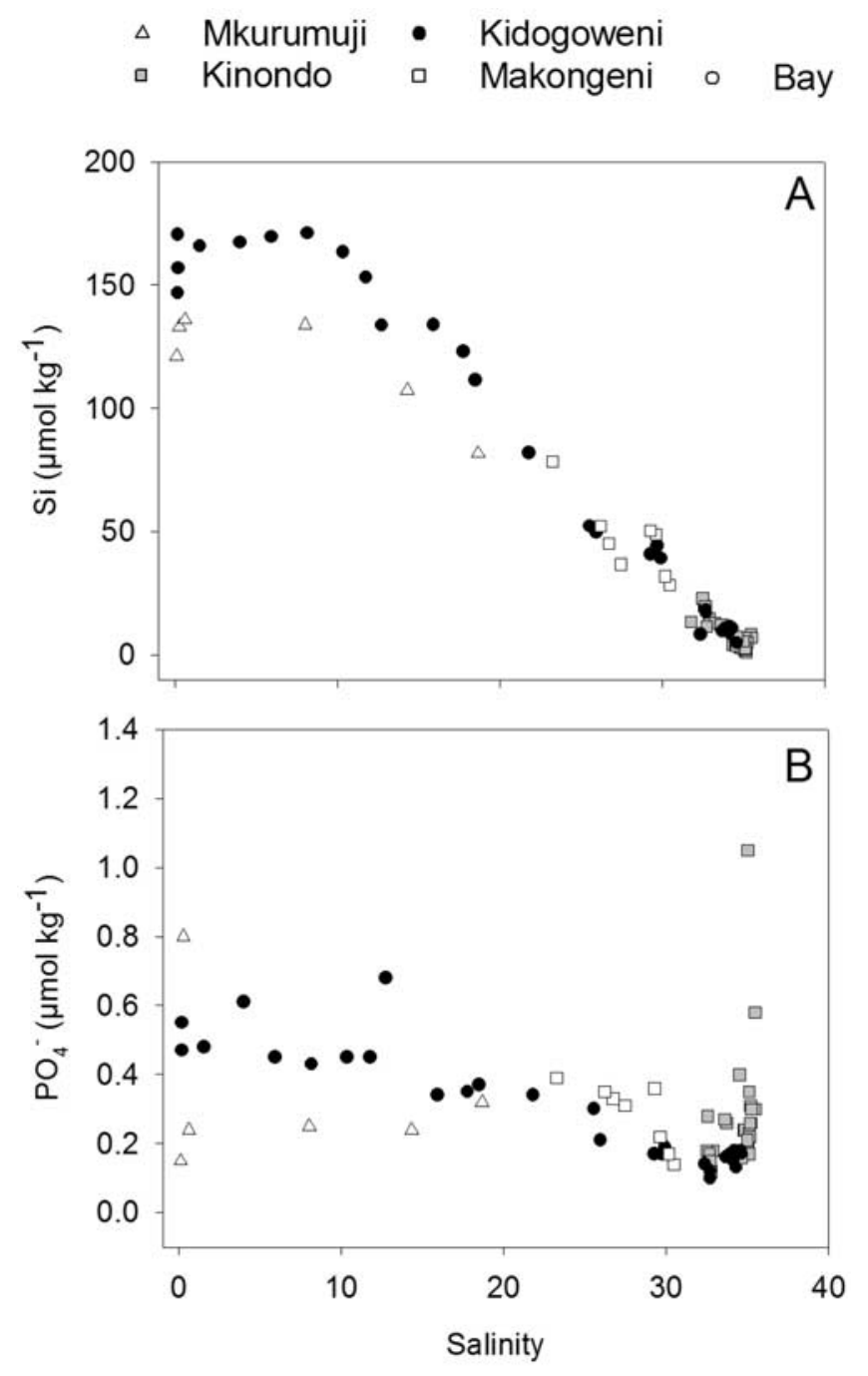

Figure 9. Distribution of (a) $\mathrm{Si}$ and (b) $\mathrm{PO}_{4}^{3-}$ concentrations along the salinity.

mineralization as evidenced from microbial phospholipid fatty acid (PLFA) $\delta^{13} \mathrm{C}$ signatures [Bouillon et al., 2004a]. It can also be noted that the $\delta^{13} \mathrm{C}$ signatures for POC in the mangrove creeks show little evidence for an important contribution by seagrass-derived carbon (e.g., along the Kidogoweni salinity gradient, only a small shift of $\sim 1 \%$ is observed toward the marine part), whereas the $\delta^{13} \mathrm{C}$ data from the seagrass beds clearly show that in the sites most adjacent to the mangrove forest, mangrove-derived $\mathrm{C}$ makes a contribution to the POC pool.

[22] In the Mkurumuji estuary, $\delta^{13} \mathrm{C}_{\mathrm{POC}}$ values are consistently more enriched than in the Kidogoweni estuary by $\sim 3-4 \%$ o (Figure 3a). These two estuaries are, however, characterized by different surrounding vegetation: The Kidogoweni estuary is entirely enclosed by extensive mangrove forests, whereas the Mkurumuji estuary has much less mangrove cover but has large areas of $\mathrm{C} 4$ grasslands in its immediate surroundings. Given that $\mathrm{C} 4$ vegetation is characterized by much more enriched $\delta^{13} \mathrm{C}$ values (typically -14 to $-12 \%$ [e.g.,
Tieszen et al., 1979]), and that POC/Chla ratios are otherwise similar in the Mkurumuji and Kidogoweni (Figure 2d), this contrast in $\delta^{13} \mathrm{C}_{\mathrm{POC}}$ is likely to be explained by a significant contribution of C4-derived carbon in this estuary. This has also been observed, although more pronounced, in the Tana estuary in northern Kenya where $\delta^{13} \mathrm{C}_{\mathrm{POC}}$ in the freshwater part of the river averaged $-21.4 \pm 0.5 \%$, equivalent to roughly $40 \%$ of the POC pool being of $\mathrm{C} 4$ origin [Bouillon et al., 2007].

\subsection{Inputs and Exchange of Organic Carbon in Mangrove and Seagrass Areas}

[23] The distribution of both POC and DOC along the salinity gradient show a marked nonconservative behavior. Significant inputs of POC and DOC along the entire salinity gradient are apparent in the Kidogoweni estuary itself, in the other mangrove creeks studied (Kinondo and Makongeni) and in the bay (Figure $2 \mathrm{~b}$ and $4 \mathrm{a}$ ). The internal production of $\mathrm{POC}$ in the different mangrove creeks is associated with little or no change in the $\delta^{13} \mathrm{C}_{\mathrm{POC}}$ which strongly suggests that the source of the added POC is mainly mangrove-derived. Indeed, the $\delta^{13} \mathrm{C}_{\mathrm{POC}}$ fits in the range of those of mangroves, and no other major primary producers with similar signatures are present in these areas. If in situ phytoplankton production was a major source of excess POC, we would expect to see a stronger gradient in $\delta^{13} \mathrm{C}_{\mathrm{POC}}$ as locally produced organic matter would have a $\delta^{13} \mathrm{C}$ that varies along with $\delta^{13} \mathrm{C}_{\mathrm{DIC}}$, the latter showing a clear curvilinear increase from $\sim-14 \%$ in the freshwater part to $\sim-2 \%$ near the mouth of the Kidogoweni (see Figure 8c). Moreover, the high $\mathrm{POC} / \mathrm{Chl}$ a ratios (Figure $2 \mathrm{~d}$ ) are not consistent with significant contributions by algal sources. This clearly indicates that significant amounts of mangrove-derived carbon are exported from the intertidal zone into the tidal creeks and the Kidogoweni estuary. In this respect, it can also be noted that several of the Kidogoweni stations show markedly higher DOC/POC ratios (Figure 4b), indicating that in some cases, the dominance of DOC in the lateral inputs of organic carbon is much higher than in the riverine inputs. This is consistent with other reports that DOC is likely to form the dominant pool of exported mangrove carbon. In several other mangrove systems, DOC was found to be the major form of organic carbon in the water column [e.g., Lee, 1995; Davis et al., 2001]. In our study, DOC comprised $65-95 \%$ of the total organic carbon pool in the water column, with DOC/POC ratios typically around 5, some higher values in the oligo- and mesohaline zone of the Kidogoweni, and a wide range of values $(1.8-14.2)$ in the seagrass beds and Kinondo creek. The local nature of the latter DOC increase suggests that the high DOC/ POC ratios observed in part of the seagrass bed stations is not merely linked to exported carbon from the mangrove forest but also to in situ production by the seagrass communities [e.g., see Maie et al., 2006], or to the release of DOC resulting from the breakdown of mangrovederived POC, which is trapped in these regions. Stable isotope measurements on the DOC pool would be needed to confirm this, in particular since recent studies have demonstrated that the origin of DOC and POC may in some cases differ substantially in coastal environments 
[e.g., Bianchi et al., 2004; Bouillon et al., 2007]. Furthermore, it should be noted that our DOC/POC ratios are markedly higher than those predicted for this region by empirical models [Ludwig et al., 1996].

[24] Water exchange rates for the Gazi Bay system have been reported to be very high $(60-90 \%$ of the volume per tidal cycle [Kitheka, 1997]), suggesting intense exchange of material between the mangrove areas and adjacent waters. Export of mangrove-derived carbon toward part of the seagrass beds was indeed evidenced by both sedimentary and water column $\delta^{13} \mathrm{C}$ signatures of organic matter [e.g., Hemminga et al., 1994; Bouillon et al., 2004a] (also this study), but a linkage beyond the seagrass zone is unlikely according to Kitheka [1997], as the coral reef flat is usually exposed at a time when seagrass water is approaching the reef zone. During high tides, however, a reversed flux of organic matter originating from the seagrass zone (i.e., resuspension of sediment organic matter) was hypothesized to occur, and seagrass material has indeed been shown to be imported into mangrove areas, both in this study site [Slim et al., 1996b; Bouillon et al., 2004a, 2004b] and in other mangrove-seagrass systems [Jaffé et al., 2001].

\subsection{Inorganic Carbon and Nutrient Dynamics}

[25] Both TA and DIC showed a clear nonconservative pattern in the Kidogoweni estuary (Figures $8 \mathrm{a}$ and $8 \mathrm{~b}$ ) and the Makongeni and Kinondo creeks, with significant internal inputs. The Mkurumuji estuary mouth was virtually closed during the time of sampling and exhibited a clear salinity stratification, the salinity mixing zone in surface waters was therefore concentrated on a very small spatial extent at the estuary mouth. As expected for such conditions, TA and DIC showed conservative behavior (Figures 8a and 8b). Conservative behavior of the dissolved inorganic carbon pool can also be examined on the basis of the $\delta^{13} \mathrm{C}_{\mathrm{DIC}}$ profiles. For a given system, the $\delta^{13} \mathrm{C}_{\mathrm{DIC}}$ profile under the assumption for conservative mixing should follow the following equation [Mook and Tan, 1991]:

$\delta^{13} C=$

$\frac{\operatorname{Sal}\left(\mathrm{DIC}_{\mathrm{F}} \delta^{13} \mathrm{C}_{\mathrm{F}}-\mathrm{DIC}_{\mathrm{M}} \delta^{13} \mathrm{C}_{\mathrm{M}}\right)+\mathrm{Sal}_{\mathrm{F}} \mathrm{DIC}_{\mathrm{M}} \delta^{13} \mathrm{C}_{\mathrm{M}}-\mathrm{Sal}_{\mathrm{M}} \mathrm{DIC}_{\mathrm{F}} \delta^{13} \mathrm{C}_{\mathrm{F}}}{\text { Sal }}$ $\mathrm{Sal}\left(\mathrm{DIC}_{\mathrm{F}}-\mathrm{DIC}_{\mathrm{M}}\right)+\mathrm{Sal}_{\mathrm{F}} \mathrm{DIC}_{\mathrm{M}}-\mathrm{Sal}_{\mathrm{M}} \mathrm{DIC}_{\mathrm{F}}$

where

$$
\begin{aligned}
& \text { Sal the sample salinity; } \\
& \mathrm{DIC}_{\mathrm{F}}, \delta^{13} \mathrm{C}_{\mathrm{F}} \text { the DIC concentration and stable isotope } \\
& \mathrm{DIC}_{\mathrm{M}}, \delta^{13 \mathrm{C}} \mathrm{C}_{\mathrm{M}}
\end{aligned}
$$

[29] Such mixing curves can be either linear (in case of equal DIC concentrations in both end-members, which is nearly the case for the Kidogoweni) or curvilinear when DIC concentrations of both end-members differ substantially (as in the Mkurumuji). As seen in Figure $8 \mathrm{c}$, the Mkurumuji $\delta^{13} \mathrm{C}_{\text {DIC }}$ data largely confirm the conservative behavior of DIC in this estuary, whereas for the Kidogoweni and other mangrove creeks, $\delta^{13} \mathrm{C}_{\mathrm{DIC}}$ values are consistently more negative than would be expected for conservative mixing. This pattern is consistent with the earlier hypothesis that intense mineralization in mangrove systems may increase the DIC in the water column, and given that the excess DIC should be isotopically similar to the organic matter from which it is derived (which could be various sources, including mangroves and benthic microalgae, with $\delta^{13} \mathrm{C}$ values in this system between -30 and $-22 \%$ [see Bouillon et al., 2004 a, Table 1]), this should result in the addition of ${ }^{13} \mathrm{C}$ depleted DIC.

[30] The relationship between salinity-normalized TA and DIC can be a useful tool to infer the causes of the TA and DIC dynamics [cf. Borges et al., 2003], since different biogeochemical processes (calcium carbonate dissolution, aerobic mineralization, sulfate reduction, etc.) have a different effect on TA and DIC. We normalized DIC data for the Kidogoweni and mangrove creeks according to [cf. Friis et al., 2003],

$$
\mathrm{DIC}_{\mathrm{n}}=\mathrm{DIC}_{x}-\alpha\left(\mathrm{sal}_{\mathrm{x}}-\mathrm{sal}_{\mathrm{n}}\right)
$$

where

$\mathrm{DIC}_{\mathrm{n}}$ the salinity-normalized DIC;

$\mathrm{DIC}_{\mathrm{x}}$ the sample DIC;

$\mathrm{Sal}_{\mathrm{x}}$ the salinity of the given sample;

$\mathrm{Sal}_{\mathrm{n}}$ the salinity to which the data are normalized (in our case, 17);

$\alpha$ the slope of the conservative mixing curve of DIC, determined from the DIC values at the two most extreme salinity values.

[36] A similar equation was used to normalize TA $\left(\mathrm{TA}_{n}\right)$. $\mathrm{DIC}_{\mathrm{n}}$ and $\mathrm{TA}_{\mathrm{n}}$ data for the Kidogoweni, Kinondo and Makongeni are well correlated $\left(\mathrm{r}^{2}=0.95\right)$ showing that their variations are controlled by the same biogeochemical process(es), and the slope of $\mathrm{TA}_{n}$ versus $\mathrm{DIC}_{n}(0.81)$ is close to the one predicted by denitrification (Figure 10). However, denitrification is typically considered as a minor diagenetic carbon degradation pathway, sulfate reduction and aerobic respiration often being the major pathways in mangrove sediments [e.g., Alongi, 2005], and the combination of sulphate reduction (SR) and aerobic respiration could explain the covariation of $\mathrm{TA}_{n}$ and $\mathrm{DIC}_{n}$ (Figure 10). $\mathrm{SR}$ can have a permanent effect on water column TA if one of the following processes occurs: (1) dissolution of $\mathrm{CaCO}_{3}$ from protons produced by the oxidation of $\mathrm{H}_{2} \mathrm{~S}_{\text {to }} \mathrm{SO}_{4}^{2-}$ [e.g., Ku et al., 1999]; (2) $\mathrm{H}_{2} \mathrm{~S}$ is trapped in the sediment as pyrite. Dissolution of $\mathrm{CaCO}_{3}$, however, does not appear to affect $\mathrm{Ca}^{2+}$ and $\mathrm{Mg}^{2+}$ profiles during estuarine mixing: their distributions follow conservative behavior (Figure $7 \mathrm{~b}$ ), and $\mathrm{Ca} / \mathrm{Mg}$ ratios along the salinity gradient (which should be a more sensitive indicator of $\mathrm{CaCO}_{3}$ dissolution) similarly follow a conservative pattern (data not shown). Although $\mathrm{CaCO}_{3}$ dissolution has been suggested to occur in the sediments of Gazi Bay [Middelburg et al., 1996] on the basis of the different $\mathrm{CaCO}_{3}$ content of sediments in this area, our data indicate that either $\mathrm{CaCO}_{3}$ dissolution does not occur in these mangrove sediments, or it is not sufficiently important to have a significant effect on the water column DIC, TA, and $\mathrm{Ca}^{2+}$ profiles. 


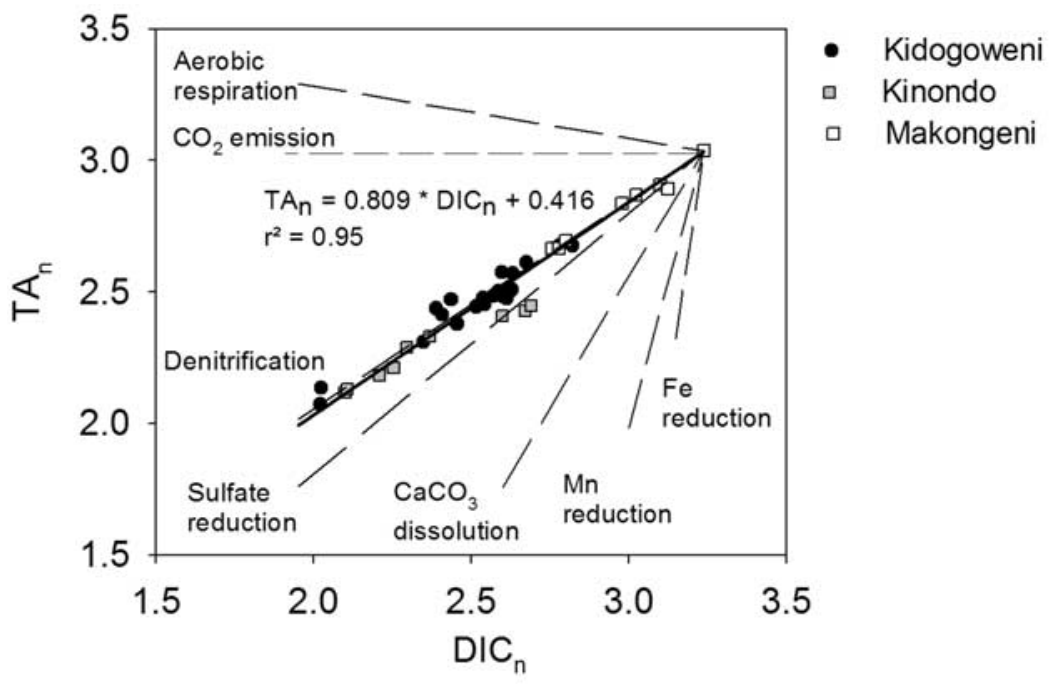

Figure 10. Covariation of salinity-normalized TA and DIC. The solid line represents the linear regression on these data; dotted lines correspond to the theoretical covariation of $\mathrm{TA}_{\mathrm{n}}$ and $\mathrm{DIC}_{\mathrm{n}}$ for various potentially acting processes.

[37] In conclusion, our data strongly suggest the role of diagenetic processes in the intertidal sediments on water column DIC and TA. Similar linear $\mathrm{DIC}_{\mathrm{n}}-\mathrm{TA}_{\mathrm{n}}$ relationships have been observed in a range of other mangrove systems [Borges et al., 2003; Bouillon et al., 2007] (also S. Bouillon and A. V. Borges, unpublished data from two Tanzanian mangrove systems), with slopes ranging between 0.61 and 1.04, although an unambiguous identification and quantitative assessment of the relative importance of the processes involved is not possible without direct measurements of pore water composition and/or sediment-water fluxes.

[38] The pattern of $\mathrm{Si}$ along the salinity gradient (Figure 9a) is similar to that observed in many temperate and tropical estuaries [e.g., Clark et al., 1992; Eyre and Balls, 1999; Dittmar and Lara, 2001], and has often been attributed to the mineralization of freshwater diatoms when they reach higher salinity levels and/or more turbid waters. On the other hand, the breakdown of terrestrial organic matter, which typically has $\mathrm{Si} / \mathrm{C}$ ratios between 0.01 and 0.04 [Conley, 2002] may also explain such a pattern. Given the low Chl a levels in our study area (Figure 2c), inputs from mineralization of terrestrial/mangrove material would appear more likely to explain the observed increase in $\mathrm{Si}$ levels ( $\sim 20 \mu \mathrm{M}$ for the Kidogoweni). Mwashote and Jumba [2002] indeed found a net outflux of Si across the sediment/ water interface in both mangroves and seagrass beds in Gazi Bay, consistent with the idea that benthic mineralization of organic matter could contribute to the increase in $\mathrm{Si}$. The magnitude of benthic Si fluxes reported by Mwashote and Jumba [2002] was similar for both habitats, and we had therefore also expected an increase of $\mathrm{Si}$ levels in the seagrass beds. Such an increase is, however, not observed (Figure 9a), either owing to a shorter water residence time in the bay and/or owing to other processes balancing the benthic Si inputs in the seagrass beds.

[39] The observed $\mathrm{PO}_{4}^{3-}$ concentrations are in the same range as those reported previously for the dry season in the
Kidogoweni river [Ohowa et al., 1997], although our data for the Mkurumuji are much lower than those reported by Ohowa et al. [1997]. Mwashote and Jumba [2002] suggested that mangroves and seagrass sediments act as, respectively, a sink and source for $\mathrm{PO}_{4}^{3-}$ during the dry season. The clear increase in $\mathrm{PO}_{4}^{3-}$ observed in the seagrass beds (Figure 9a) is consistent with such a scenario. Fluxes of $\mathrm{PO}_{4}^{3-}$ across the sediment-water interface are typically directed toward the sediment in intertidal mangrove systems [e.g., Alongi et al., 2000; Mohammed and Johnstone, 2002], but the distribution of $\mathrm{PO}_{4}^{3-}$ along the Kidogoweni salinity gradient does not show a very distinct nonconservative pattern, suggesting that sediment-water fluxes are either insignificant for the overall water column $\mathrm{PO}_{4}^{3-}$ budget, or that other process balance these fluxes.

\subsection{Water-Atmosphere Fluxes of $\mathrm{CO}_{2}$ : Ecosystem-Scale Integration}

[40] The patterns observed in the $\mathrm{pCO}_{2}$ data are consistent with the $\% \mathrm{O}_{2}$ data (Figure 11), with high $\mathrm{pCO}_{2}$ values corresponding to low oxygen saturation levels, and low $\mathrm{pCO}_{2}$ coinciding with high $\% \mathrm{O}_{2}$ (up to $\sim 200 \%$ ). This confirms that both are governed by the same processes, i.e., mineralization and photosynthesis. The spatial distribution of $\mathrm{pCO}_{2}$ and $\% \mathrm{O}_{2}$ clearly demonstrates the marked contrast between the mangrove creeks and the seagrass beds: The former are characterized by high $\mathrm{pCO}_{2}$ and low $\% \mathrm{O}_{2}$, while some areas of the bay (in particular the shallow southeastern part near Chale Island) show undersaturation in $\mathrm{CO}_{2}$ and a large oversaturation in $\mathrm{O}_{2}$, reflecting intense photosynthesis by the dense seagrass beds. The latter situation coincides with very low $\delta^{18} \mathrm{O}_{\mathrm{DO}}$ values down to $\sim+15 \%$ (Figure $6 \mathrm{~b}$ ). The $\delta^{18} \mathrm{O}$ values of dissolved oxygen are an integrated measure, being influenced both by airwater exchange (at equilibrium, $\delta^{18} \mathrm{O}_{\mathrm{DO}}$ would be $+24.2 \%$ ), photosynthesis (producing $\mathrm{O}_{2}$ with a $\delta^{18} \mathrm{O}$ signature similar to that of the source water [see Guy et al., 1993]), and oxygen consumption by respiration, which fractionates by 


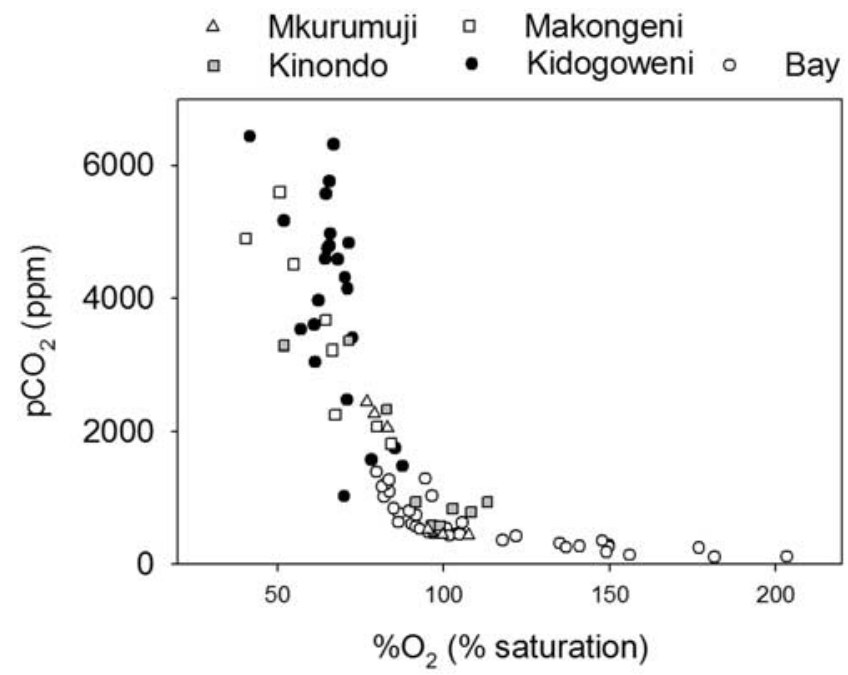

Figure 11. Relationship between $\% \mathrm{O}_{2}$ and $\mathrm{pCO}_{2}$.

$\sim 18 \%$ o thereby rendering the residual $\mathrm{O}_{2}$ pool enriched in ${ }^{18}$ O [e.g., Quay et al., 1995; Wang and Veizer, 2000]. Since the $\delta^{18} \mathrm{O}$ signature of the water in this system ranges linearly between $\sim-2 \%$ in the freshwater end-member and $+0.5 \%$ for the bay area (data not shown), the low $\delta^{18} \mathrm{O}_{\mathrm{DO}}$ signatures in some of the seagrass stations demonstrate that the high oxygen levels are primarily due to photosynthetic $\mathrm{O}_{2}$ inputs.

[41] We estimated the flux of $\mathrm{CO}_{2}(\mathrm{~F})$ across the water-air interface according to

$$
\mathrm{F}=k \alpha \Delta \mathrm{pCO}_{2}
$$

where $k$ is the gas transfer velocity, $\alpha$ the solubility coefficient for $\mathrm{CO}_{2}$, and $\Delta \mathrm{pCO}_{2}$ represents the difference in $\mathrm{pCO}_{2}$ between water and air. $k$ values in coastal environments are to a large extent determined by wind stress and other site-specific factors such as water currents and fetch limitation [Borges et al., 2004]. We considered the $k$-wind parameterization proposed by Carini et al. [1996] for consistency with the flux computations in other mangrove studies [Borges et al., 2003; Bouillon et al., 2007] and by Raymond and Cole [2001] that is a generic (yet conservative) $k$-wind parameterization for estuarine environments.

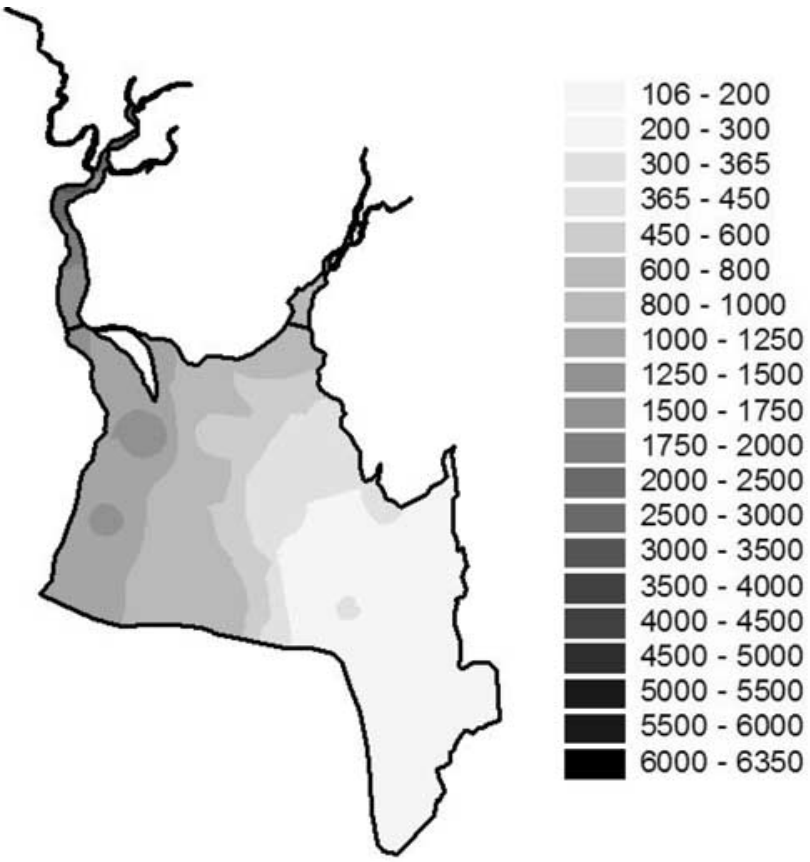

Figure 12. Spatial distribution of $\mathrm{pCO}_{2}$. Values were interpolated as explained in Table 2.

[42] Mangrove systems typically show high water column $\mathrm{pCO}_{2}$ levels and $\mathrm{CO}_{2}$ efflux to the atmosphere ( $\sim 50 \mathrm{mmol} \mathrm{m} \mathrm{m}^{-1}$ [see Borges, 2005; Borges et al., 2005]), suggesting that this could be a major pathway in the carbon budget of these ecosystems [e.g., Borges et al., 2003; Bouillon et al., 2003] and even in the global oceanic $\mathrm{CO}_{2}$ budget [Borges et al., 2005]. Reliable estimates on the surface areas over which these fluxes should be extrapolated, however, are missing. A further complicating issue is the fact that large spatial variability may occur in $\mathrm{pCO}_{2}$, wind speed, and the resulting $\mathrm{CO}_{2}$ fluxes, which could bias the average values used in ecosystem-scale extrapolations.

[43] Given that our sampling strategy aimed to provide a good spatial coverage and full coverage of the salinity range, we evaluated the strength of this potential bias and the importance of different water bodies in the overall $\mathrm{CO}_{2}$ efflux of the ecosystem studied here. We used a geographical information system (ArcView ${ }^{\mathrm{C}}$ with Spatial Analyst ${ }^{\mathrm{C}}$ ) to interpolate the $\mathrm{pCO}_{2}$ and flux data (see Table 2 for details), and subsequently integrated these estimates for

Table 2. Overview of Average $\mathrm{pCO}_{2}$ Values Obtained by the Mean on the Individual Measurements, and Obtained After Spatial Interpolation of $\mathrm{pCO}_{2}$ Data in ArcView With Spatial Analyst ${ }^{\mathrm{a}}$

\begin{tabular}{llc}
\hline \multicolumn{1}{c}{ Region } & \multicolumn{1}{c}{ Average \pm s.d. } & $\begin{array}{c}\text { Spatially Explicit } \\
\text { Average }\end{array}$ \\
\hline Kinondo & $1514 \pm 1153(\mathrm{n}=9)$ & $847 \pm 413(\mathrm{n}=2420)$ \\
Kidogoweni and side creeks & $3873 \pm 1498(\mathrm{n}=31)$ & $2394 \pm 1014(\mathrm{n}=7295)$ \\
Bay (seagrass beds only) & $584 \pm 339(\mathrm{n}=43)$ & $559 \pm 356(\mathrm{n}=176170)$ \\
\hline
\end{tabular}

${ }^{\mathrm{a}}$ Here $\mathrm{n}$ in the second and third columns refers to the number of individual measurements and grid cells, respectively. Interpolations were performed using a grid size of $5 \times 5 \mathrm{~m}$, and taking 4 neighboring data points into account. Boundaries were set up between the different sidearms of the creeks, so that data in one creek could not be influenced by data from an adjacent creek arm. The system boundaries over which these computations were performed were based on the exact sampling locations and, for the bay area, coincided with the approximate extent of the seagrass cover. 

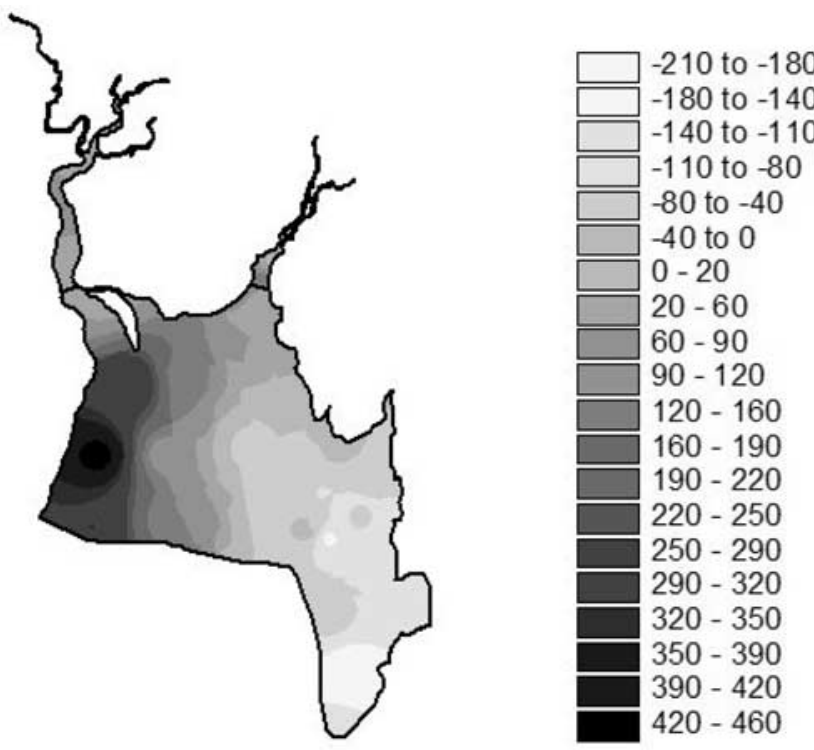

Figure 13. Spatial distribution of the estimated water-air $\mathrm{CO}_{2}$ flux using the $k$-wind parameterization by Raymond and Cole [2001]. Values (in $\mathrm{mmol} \mathrm{m} \mathrm{m}^{-2} \mathrm{~d}^{-1}$ ) were interpolated as explained in Table 2.

three different regions (Kidogoweni and side creeks, Kinondo, and the upper part of the bay).

[44] The interpolated data show a markedly different pattern for the $\mathrm{pCO}_{2}$ distribution and that of the areal $\mathrm{CO}_{2}$ air-water fluxes (Figures 12 and 13): whereas $\mathrm{pCO}_{2}$ values are consistently highest in the upper reaches of the mangrove creeks and decrease in a southeastern direction over the seagrass beds (see also Figure 8d), the air-water $\mathrm{CO}_{2}$ fluxes over the water/air interface also show a local maximum above the seagrass beds in the northwestern part of the Bay (Figure 13). This is due to the effect of wind speed on $k$ and rate of $\mathrm{CO}_{2}$ exchange, which is lower in the creeks owing to the dampening effect of the surrounding forest. Water oversaturated in $\mathrm{CO}_{2}$ entering the bay area is exposed to much higher wind speeds, resulting in a maximum in the air-water $\mathrm{CO}_{2}$ exchange rates in this region. The total water column $\mathrm{CO}_{2}$ efflux amounts to roughly $30-70 \%$ of the estimated total mangrove litter production (assuming $6 \mathrm{~km}^{2}$ of mangrove cover and productivity data mentioned in section 2). When including seagrass production and assuming a similar areal cover, total $\mathrm{CO}_{2}$ efflux represents an estimated $6-13 \%$ of the total production. Despite the uncertainties in our productivity estimates and our very limited temporal data coverage, this indicates that the potential of mineralization and $\mathrm{CO}_{2}$ efflux in the overall ecosystem budget is likely to be substantial, in particular since $\mathrm{CO}_{2}$ exchange in the large intertidal mangrove areas is not included in these estimates. This fits well with the scenario proposed by Cai et al. [1999] for estuarine salt marshes, whereby considerable amounts of respiratory $\mathrm{CO}_{2}$ (as DIC) are exported from intertidal areas into the estuary where conditions are more favorable to water-air exchange.

[45] The distinct spatial gradient in $\mathrm{pCO}_{2}$ and $\mathrm{CO}_{2}$ efflux can result in a significant bias between the average interpolated values and the average of the individual data points or flux estimates (Tables 2 and 3). If we use only the creek water surface in our computations, it becomes evident that, despite the much higher $\mathrm{pCO}_{2}$ levels in the mangrove creeks than in the seagrass beds where some areas are net sinks of $\mathrm{CO}_{2}$ (Figure 8d), the combined effect of the relative surface areas over which $\mathrm{CO}_{2}$ exchange takes place and the higher wind speed in the open seagrass is that the majority of $\mathrm{CO}_{2}$ exchange takes place in areas adjacent to the mangrove forest (Table 3 and Figure 13).

[46] Our results show that the spatial variability of airwater $\mathrm{CO}_{2}$ fluxes and the way it is accounted for while averaging results induces a bias in the $\mathrm{CO}_{2}$ efflux estimates at ecosystem scale that is similar in magnitude than the one introduced by the choice of $k$-wind parameterizations (Table 3). Moreover, recent studies in estuarine environments show that the Raymond and Cole [2001] parameterization provides conservative $k$ estimates for systems where tidal currents are significant [Zappa et al., 2003; Borges et al., 2004]. As for estuaries, reliable areal airwater $\mathrm{CO}_{2}$ fluxes should be based on site specific $k$-wind relationships, requiring integrated and trans-disciplinary studies of these ecosystems. Finally, to our best knowledge, no measurements are available on the flooded intertidal areas; all studies have been so far carried out in tidal creek waters. Data on $\mathrm{CH}_{4}$ and $\mathrm{N}_{2} \mathrm{O}$ in the mangroves of Andaman Islands (India) suggest that the water to air emission of these gases is strongly enhanced over flooded intertidal areas compared to permanently

Table 3. Overview of Estimated Water-Air $\mathrm{CO}_{2}$ Fluxes Obtained by Mean on the Individual Measurements, and Obtained After Spatial Interpolation of the Flux Estimates in ArcView With Spatial Analyst ${ }^{\mathrm{a}}$

\begin{tabular}{lcccc}
\hline \multicolumn{1}{c}{ Region } & $\begin{array}{c}\text { Area, } \\
\mathrm{km}^{2}\end{array}$ & $\begin{array}{c}\text { Average } \pm 1 \text { s.d., } \\
\mathrm{mmol} \mathrm{m}^{-2} \mathrm{~d}^{-1}\end{array}$ & $\begin{array}{c}\text { Spatially Extrapolated } \\
\text { Average, } \mathrm{mmol} \mathrm{m}^{-2} \mathrm{~d}^{-1}\end{array}$ & $\begin{array}{c}\text { Total CO Efflux, } \\
10^{3} \mathrm{~mol} \mathrm{~d}^{-1}\end{array}$ \\
\hline Kinondo & 0.061 & $43 \pm 44^{\mathrm{b}}$ & $52 \pm 42^{\mathrm{b}}$ & $3.2^{\mathrm{b}}$ \\
& & $21 \pm 22^{\mathrm{c}}$ & $29 \pm 18^{\mathrm{c}}$ & $1.7^{\mathrm{c}}$ \\
Kidogoweni and side creeks & 0.182 & $101 \pm 91^{\mathrm{b}}$ & $71 \pm 43^{\mathrm{b}}$ & $13.0^{\mathrm{b}}$ \\
Bay (seagrass beds only) & 4.004 & $39 \pm 116^{\mathrm{b}}$ & $65 \pm 49^{\mathrm{c}}$ & $11.9^{\mathrm{c}}$ \\
& & $23 \pm 42^{\mathrm{c}}$ & $56 \pm 150^{\mathrm{b}}$ & $248.1^{\mathrm{b}}$ \\
Entire system & 4.647 & $192.8^{\mathrm{b}}$ & & $106.9^{\mathrm{c}}$ \\
& & $115.9^{\mathrm{c}}$ & & $264.2^{\mathrm{b}}$ \\
\hline
\end{tabular}

${ }^{\mathrm{a}}$ For details see Table 2 .

${ }^{\mathrm{b}}$ Flux estimates were calculated using the $k$-wind parameterizations by Raymond and Cole [2001].

${ }^{\mathrm{c}}$ Flux estimates were calculated using the $k$-wind parameterizations by Carini et al. [1996]. 
submerged tidal creeks [Barnes et al., 2006] and this could probably also be the case for $\mathrm{CO}_{2}$.

\section{Concluding Remarks}

[47] Mangrove and seagrass-derived organic matter were found to be the dominant sources of water column organic carbon, and showed a distinct spatial distribution, with a sharp transition in their relative dominance at the mangroveseagrass transition. Mineralization in intertidal sediments and subsequent export of the mineralization products to the tidal creeks resulted in low $\% \mathrm{O}_{2}$ and high $\mathrm{pCO}_{2}$ in the mangrove creeks, whereas toward the seagrass beds, the system clearly shifted toward an autotrophic status, with high $\mathrm{O}_{2}$ oversaturation, high $\delta^{18} \mathrm{O}_{\mathrm{DO}}$, and low $\mathrm{pCO}_{2}$. The seagrass beds appeared to be very efficient in trapping mangrove-derived organic matter, and provided a large surface area strongly influenced by wind stress for the atmospheric exchange of excess $\mathrm{CO}_{2}$ transported from the mangrove waters. Water-air exchange of $\mathrm{CO}_{2}$ likely represents a significant component in the ecosystems' $\mathrm{C}$ budget. Given the complex nature of this dynamic ecosystem, detailed process rate measurements with a well-designed spatial and seasonal sampling strategy that account for the relevant scales of variability are needed to adequately constrain the overall $\mathrm{C}$ budget, including more comprehensive coverage of primary production and mineralization rates, and quantifying dissolved and particulate exchange fluxes. Our data indicate that source characterization is an important aspect of such studies, and that quantifying overall mineralization in these systems should include the $\mathrm{CO}_{2}$ exchange during inundation in tidal forests.

[48] Acknowledgments. S. B. is funded by a postdoctoral mandate from the Research Foundation Flanders (FWO-Vlaanderen). Financial support was provided by the FWO-Vlaanderen (contract G.0118.02 and a travel grant to S. B.), the EC-project PUMPSEA (FP6-INCO contract 510863), and by the FNRS (contracts 2.4596.01 and 1.5.066.03) where A. V. B. is a research associate. We are grateful to J. G. Kairo and J. Bosire for their excellent help in organizing the logistics during fieldwork, to $\mathrm{H}$. Etcheber for assistance with the DOC analysis, to L. Chou for assistance with the inorganic nutrient analysis, and to D. P. Gillikin for constructive comments on an earlier version of this manuscript. We also wish to thank R. Jaffé and an anonymous referee for their thoughtful and constructive comments on the original manuscript. This is publication 4007 of the Netherlands Institute of Ecology (NIOO-KNAW).

\section{References}

Abril, G., E. Nogueira, H. Hetcheber, G. Cabeçadas, E. Lemaire, and M. J. Brogueira (2002), Behaviour of organic carbon in nine contrasting European estuaries, Estuarine Coastal Shelf Sci., 54, 241-262.

Alongi, D. M. (2005), Mangrove-microbe-soil relations, in Interactions Between Macro- and Microorganisms in Marine Sediments, Coastal Estuarine Stud., vol. 60, edited by E. Kristensen, J. E. Kostka, and R. H. Haese, pp. 85-103, AGU, Washington, D. C.

Alongi, D. M., E. Tirendi, and F. Clough (2000), Below-ground decomposition of organic matter in forests of the mangroves Rhizophora stylosa and Avicennia marina along the arid coast of Western Australia, Aquat. Bot., 68, 97-122.

Barnes, J., R. Ramesh, R. Purvaja, A. Nirmal Rajkumar, B. Senthil Kumar, K. Krithika, K. Ravichandran, G. Uher, and R. Upstill-Goddard (2006), Tidal dynamics and rainfall control $\mathrm{N}_{2} \mathrm{O}$ and $\mathrm{CH}_{4}$ emissions from a pristine mangrove creek, Geophys. Res. Lett., 33, L15405, doi:10.1029/ 2006GL026829.

Bianchi, T. S., T. Filley, K. Dria, and P. G. Hatcher (2004), Temporal variability in sources of dissolved organic carbon in the lower Mississippi River, Geochim. Cosmochim. Acta, 68, 959-967.

Borges, A. V. (2005), Do we have enough pieces of the jigsaw to integrate $\mathrm{CO}_{2}$ fluxes in the Coastal Ocean?, Estuaries, 28, 3-27.
Borges, A. V., S. Djenidi, G. Lacroix, J. Théate, B. Delille, and M. Frankignoulle (2003), Atmospheric $\mathrm{CO}_{2}$ flux from mangrove surrounding waters, Geophys. Res. Lett., 30(11), 1558, doi:10.1029/2003GL017143.

Borges, A. V., B. Delille, L. S. Schiettecatte, F. Gazeau, G. Abril, and M. Frankignoulle (2004), Gas transfer velocities of $\mathrm{CO}_{2}$ in three European estuaries (Randers Fjord Scheldt and Thames), Limnol. Oceanogr., 49, 1630-1641.

Borges, A. V., B. Delille, and M. Frankignoulle (2005), Budgeting sinks and sources of $\mathrm{CO}_{2}$ in the coastal ocean: Diversity of ecosystems counts, Geophys. Res. Lett., 32, L14601, doi:10.1029/2005GL023053.

Bouillon, S., M. Frankignoulle, F. Dehairs, B. Velimirov, A. Eiler, H. Etcheber, G. Abril, and A. V. Borges (2003), Inorganic and organic carbon biogeochemistry in the Gautami Godavari estuary (Andhra Pradesh, India) during pre-monsoon: The local impact of extensive mangrove forests, Global Biogeochem. Cycles, 17(4), 1114, doi:10.1029/2002GB002026.

Bouillon, S., T. Moens, and F. Dehairs (2004a), Carbon sources sustaining benthic mineralization in mangrove and adjacent seagrass sediments (Gazi Bay Kenya), Biogeosciences, 1, 71-78.

Bouillon, S., T. Moens, I. Overmeer, N. Koedam, and F. Dehairs (2004b), Resource utilization patterns of epifauna from mangrove forests with contrasting inputs of local versus imported organic matter, Mar. Ecol. Prog. Ser., 278, 77-88

Bouillon, S., F. Dehairs, L. S. Schiettecatte, and A. V. Borges (2007), Biogeochemistry of the Tana estuary and delta (northern Kenya), Limnol. Oceanogr., 52, 46-57.

Cai, W.-J., L. R. Pomeroy, M. A. Moran, and Y. Wang (1999), Oxygen and carbon dioxide mass balance in the estuarine/intertidal marsh complex of five rivers in the southeastern U. S., Limnol. Oceanogr., 44, 639-649.

Carini, S., N. Weston, C. Hopkinson, J. Tucker, A. Giblin, and J. Vallino (1996), Gas exchange rates in the Parker River estuary, Massachusetts, Biol. Bull., 191, 333-334.

Clark, J. F., H. J. Simpson, R. F. Bopp, and B. Deck (1992), Geochemistry and loading history of phosphate and silicate in the Hudson Estuary, Estuarine Coastal Shelf Sci., 34, 213-233.

Conley, D. J. (2002), Terrestrial ecosystems and the global biogeochemical silica cycle, Global Biogeochem. Cycles, 16(4), 1121, doi:10.1029 2002GB001894

Coppejans, E., H. Beeckman, and M. De Wit (1992), The seagrass and associated macroalgal vegetation of Gazi Bay (Kenya), Hydrobiologia, $247,59-75$

Davis, S. E., III, D. L. Childers, J. W. Day, D. T. Rudnick, and F. H. Sklar (2001), Wetland-water column exchanges of carbon, nitrogen, and phosphorus in a southern Everglades dwarf mangrove, Estuaries, 24, 610-622.

Dittmar, T., and R. J. Lara (2001), Do mangroves rather than rivers provide nutrients to coastal environments south of the Amazon River? Evidence from long-term flux measurements, Mar. Ecol. Prog. Ser., 213, 67-77.

Dittmar, T., N. Hertkorn, G. Kattner, and R. Lara (2006), Mangroves, a major source of dissolved organic carbon to the oceans, Global Biogeochem. Cycles, 20, GB1012, doi:10.1029/2005GB002570.

Duarte, C. M., and J. Cebrián (1996), The fate of marine autotrophic production, Limnol. Oceanogr., 41, 1758-1766.

Eyre, B., and P. Balls (1999), A comparative study of nutrient behavior along the salinity gradient of tropical and temperate estuaries, Estuaries, $22,313-326$.

Frankignoulle, M., and A. V. Borges (2001), Direct and indirect $\mathrm{pCO}_{2}$ measurements in a wide range of $\mathrm{pCO}_{2}$ and salinity values (the Scheldt Estuary), Aquat. Geochem., 7, 273-627.

Friis, K., A. Körtzinger, and D. W.R. Wallace (2003), The salinity normalization of marine inorganic carbon chemistry data, Geophys. Res. Lett., 30(2), 1085, doi:10.1029/2002GL015898.

Grasshoff, K., M. Ehrhardt, and K. Kremling (1983), Methods of Seawater Analysis, Verlag Chemie, Basel, Switzerland.

Guy, R. D., M. L. Fogel, and J. A. Berry (1993), Photosynthetic fractionation of the stable isotopes of oxygen and carbon, Plant Physiol., 101, 37-47.

Hemminga, M. A., F. J. Slim, J. Kazungu, G. M. Ganssen, J. Nieuwenhuize, and N. M. Kruyt (1994), Carbon outwelling from a mangrove forest with adjacent seagrass beds and coral reefs (Gazi Bay Kenya), Mar. Ecol. Prog. Ser., 106, 291-301.

Hemminga, M. A., P. Gwada, F. J. Slim, P. de Koeyer, and J. Kazungu (1995), Leaf production and nutrient contents of the seagrass Thalassodendron ciliatum in the proximity of a mangrove forest (Gazi Bay, Kenya), Aquat. Bot., 50, 159-170.

Hobbie, J. E., R. J. Dayley, and S. Jasper (1977), Use of Nucleopore filters for counting bacteria by epifluorescence microscopy, Appl. Environ. Microbiol., 33, 1225-1228.

Jaffé, R., R. Mead, M. E. Hernandez, M. C. Peralba, and O. A. DiGuida (2001), Origin and transport of sedimentary organic matter in two subtropical estuaries: A comparative, biomarker-based study, Org. Geochem., 32, 507-526. 
Jennerjahn, T. C., and V. Ittekkot (2002), Relevance of mangroves for the production and deposition of organic matter along tropical continental margins, Naturwissenschaften, 89, 23-30.

Kitheka, J. U. (1997), Coastal tidally-driven circulation and the role of water exchange in the linkage between tropical coastal ecosystems, Estuarine Coastal Shelf Sci., 45, 177-187.

Kitheka, J. U., B. O. Ohowa, B. M. Mwashote, W. S. Shimbira, J. M. Mwaluma, and J. Kazungu (1996), Water circulation dynamics, water column nutrients and plankton productivity in a well-flushed tropical bay in Kenya, J. Sea Res., 35, 257-268.

Ku, T. C.W., L. M. Walter, M. L. Coleman, R. E. Blake, and A. M. Martini (1999), Coupling between sulfur recycling and syndepositional carbonate dissolution: Evidence from oxygen and sulfur isotope composition of pore water sulfate South Florida Platform, U. S. A., Geochim. Cosmochim. Acta, 63, 2529-2546.

Lee, S. Y. (1995), Mangrove outwelling: A review, Hydrobiologia, 295, $203-212$.

Ludwig, W., J. L. Probst, and S. Kempe (1996), Predicting the oceanic input of organic carbon by continental erosion, Global Biogeochem. Cycles, 10, 23-41.

Maie, N., J. N. Boyer, C. Yang, and R. Jaffé (2006), Spatial, geomorphological, and seasonal variability of CDOM in estuaries of the Florida Coastal Everglades, Hydrobiologia, 569, 135-150.

Middelburg, J. J., J. Nieuwenhuize, F. J. Slim, and B. Ohowa (1996), Sediment biogeochemistry in an East African mangrove forest (Gazi Bay, Kenya), Biogeochemistry, 34, 133-155.

Miyajima, T., Y. Yamada, Y. T. Hanba, K. Yoshii, T. Koitabashi, and E. Wada (1995), Determining the stable-isotope ratio of total dissolved inorganic carbon in lake water by GC/C/IRMS, Limnol. Oceanogr., 40 , 994-1000.

Mohammed, S. M., and R. W. Johnstone (2002), Porewater nutrient profiles and nutrient sediment-water exchange in a tropical mangrove waterway, Mapopwe Creek, Chwaka Bay, Zanzibar, Afr. J. Ecol., 40, 172-178.

Mook, W. G., and T. C. Tan (1991), Stable carbon isotopes in rivers and estuaries, in Biogeochemistry of Major World Rivers, edited by E. T. Degens et al., pp. 245-264, John Wiley, Hoboken, N. J.

Mwashote, B. M., and I. O. Jumba (2002), Quantitative aspects of inorganic nutrient fluxes in the Gazi Bay (Kenya): Implications for coastal ecosystems, Mar. Pollut. Bull., 44, 1194-1205.

Norland, S. (1993), The relationship between biomass and volume of bacteria, in Current Methods in Aquatic Microbial Ecology, edited by P. F. Kemp et al., pp. 303-307, Lewis, Boca Raton, Fla.

Ochieng, C. A., and P. L.A. Erftemeijer (2002), Phenology, litterfall and nutrient resorption in Avicennia marina (Forssk.) Vierh in Gazi Bay, Kenya, Trees, $165,167-171$.
Ohowa, B. O., B. M. Mwashote, and W. S. Shimbira (1997), Dissolved inorganic nutrient fluxes from two seasonal rivers into Gazi Bay, Kenya, Estuarine Coastal Shelf Sci., 45, 189-195.

Quay, P. D., D. O. Wilbur, J. E. Richey, A. H. Devol, R. Benner, and B. R. Forsberg (1995), The 180:16O of dissolved oxygen in rivers and lakes in the Amazon Basin: Determining the ratio of respiration to photosynthesis in freshwaters, Limnol. Oceanogr., 40, 718-729.

Raymond, P. A., and J. J. Cole (2001), Gas exchange in rivers and estuaries: Choosing a gas transfer velocity, Estuaries, 24, 312-317.

Slim, F. J., P. M. Gwada, M. Kodjo, and M. A. Hemminga (1996a), Biomass and litterfall of Ceriops tagal and Rhizophora mucronata in the mangrove forest of Gazi Bay Kenya, Mar. Freshwater Res., 47, 9991007 .

Slim, F. J., M. A. Hemminga, and G. van der Velde (1996b), Tidal exchange of macrolitter between a mangrove forest and adjacent seagrass beds (Gazi Bay, Kenya), Neth. J. Aquat. Ecol., 30, 119-128.

Tieszen, L. L., M. M. Senyimba, and S. K. Imbamba (1979), The distribution of $\mathrm{C} 3$ and $\mathrm{C} 4$ grasses and carbon isotope discrimination along and altitudinal and moisture gradient in Kenya, Oecologia, 37, 337-350.

Velimirov, B., and M. Valenta-Simon (1992), Seasonal changes in specific growth rates, production and biomass of a bacterial community in the water column above a Mediterranean seagrass system, Mar. Ecol. Prog. Ser., 80, 237-248.

Wang, X., and J. Veizer (2000), Respiration/photosynthesis balance of terrestrial aquatic ecosystems, Ottawa area, Canada, Geochim. Cosmochim. Acta, 64, 3775-3786.

Xu, Y., R. N. Mead, and R. Jaffé (2006), A molecular-based assessment of sedimentary organic matter sources and distributions in Florida Bay, Hydrobiologia, 569, 179-192.

Zappa, C. J., P. A. Raymond, E. A. Terray, and W. R. McGillis (2003), Variation in surface turbulence and the gas transfer velocity over a tidal cycle in a macro-tidal estuary, Estuaries, 26, 1401-1415.

G. Abril, Environnements et Paléoenvironnements Océaniques (EPOC) CNRS-UMR 5805, Université Bordeaux 1, Avenue des facultés, F-33405, Talence, France.

A. V. Borges, Unité d'Océanographie Chimique, MARE, Université de Liège, B-4000, Sart Tilman, Belgium.

S. Bouillon and F. Dehairs, Department of Analytical and Environmental Chemistry, Vrije Universiteit Brussel, Pleinlaan 2, B-1050 Brussels, Belgium. (steven.bouillon@vub.ac.be)

B. Velimirov, Center for Anatomy and Cell Biology, Medical University of Vienna, Währingerstr. 10, A-1090 Vienna, Austria. 